Thomas Poulsen

\title{
Private benefits in corporate control transactions
}

Finance

Research Group 


\title{
Private benefits in corporate control transactions
}

\author{
Thomas Poulsen* \\ Finance Research Group \\ Department of Business Studies \\ Aarhus School of Business \\ University of Aarhus \\ E-mail: thpo@asb.dk
}

This version: February 8, 2008

\footnotetext{
*Discussions, suggestions, and comments from Artur Raviv, Annette Vissing-Jorgensen, Randall Morck, Henri Servaes, Steen Thomsen, Tom Aabo, Morten Bennedsen, Jan Bartholdy, and Morten Balling are gratefully acknowledged. This work was partly done while visiting Department of Finance at Kellogg School of Management, Northwestern University. Their kind hospitality is gratefully acknowledged as well.
} 


\section{Abstract}

This paper presents an analytical framework from which it can be inferred whether sellers or buyers in corporate control transactions value private benefits highest. I am thus able to suggest an answer to the question: Are blocks of shares traded because the buyer is a more efficient monitor with high security benefits, or because the buyer has high private benefits from the control rights that come with the shares? Using voting rights as the vehicle for private benefits, I find that the selling shareholders in block transactions attach more value to private benefits than the buyers. In tender offer transactions, the answer is that private benefits are insignificant to both sides of the transaction. As an alternative measure of the transaction premium, I calculate the abnormal return premium. This represents the stock market's valuation of the transaction. I find that the stock market puts a positive premium on the sample transactions. Although this is not confirmed by the regression results, the market therefore expects higher future security benefits. The negative coefficients of relative voting power lend support to this conclusion, but they are not significant. I also find that inside shareholders have a very small effect on these results, but that they do attach more value to private benefits.

JEL Classification: G30, G32, G34

Keywords: Private benefits, security benefits, corporate control, block transactions, tender offers, ownership structure, influence, voting power 


\section{Introduction}

Takeovers are important in the dynamic allocation of corporate control, and a wellfunctioning market for corporate control is a key component of an effective governance system (Manne [1965], Jensen [1988]). However, with corporate control come conflicts of interest and the opportunity to make discretionary decisions. It is widely recognized that the substantial premiums paid for shares in takeovers, which are defined as transactions that involves a majority of the voting rights, in part reflect compensation to the selling shareholders for surrendering valuable voting control.

However, corporate control does not necessarily require a majority of the votes. When the remaining shares are dispersed, a minority block may be sufficient. Control is taken to mean the ownership of sufficient voting power to take decisions on important company matters (Nenova [2003]). In transactions that involve less than a majority of the votes, the seller also expects some private benefits that are not received by other shareholders and that increase with the number of shares transacted (Barclay and Holderness [1989], Mikkelson and Regassa [1991]).

Thus, the value of the shares transacted, whether it is a minority or majority, is the expected value of security benefits paid to all shareholders in proportion of ownership stake plus the expected value of private benefits that are in addition to security benefits. This distinction raises the question why blocks of shares are traded. Is it because the buyer is a more efficient monitor with high security benefits, or is it because the buyer is a less efficient monitor with high private benefits? In other words, is it a way to profit from a correction of managerial failure, or is it simply a way to obtain private benefits? I focus on blocks of shares (target firms with blockholders) because it requires a certain amount of voting rights to realize any significant private benefits.

Despite their private nature, the existence of private benefits is documented in studies of block transactions (Barclay and Holderness [1989], Dyck and Zingales [2004]) and 
voting premiums (Lease et al. [1983], Lease et al. [1984], Zingales [1994], Nenova [2003]), ${ }^{1}$ but not much is known about their significance relative to security benefits in corporate control transactions. This paper develops an analytical framework from which it can be inferred whether sellers or buyers value private benefits highest. If the selling shareholders attach more value to private benefits than buyers, I consider the transaction socially efficient in the sense that control is passed to shareholders who value the firm for its security benefits, which all shareholders profit from (positive externalities of control), and not private benefits, which expropriate other, typically small, shareholders (negative externalities of control). A successful transaction thus indicates that the buyers are able to produce enough security benefits to compensate the selling shareholders for giving up high private benefits without making the transaction unattractive.

In this paper, voting rights are the vehicle for private benefits. The key assumption is that private benefits are divisible and allocated to each shareholder according to the shareholder's voting power (Zwiebel [1995]). Voting power is the probability that a block of shares is pivotal for achieving control of a firm in a voting contest. If the blockholders' probability of being pivotal is high, their share of the fixed payoff available to the winning coalition, which is the same as their expected private benefits, is high. Private benefits therefore depend on the size of the block, but also on the distribution of the remaining shares. A minority shareholder has less influence when there is another large minority shareholder than when the remaining shareholders are small and dispersed. I use relative voting power, defined as voting power divided by voting rights, to distinguish between preferences for security benefits and private benefits. If the relative voting power is larger than 1 , it is considered to reflect a preference for private benefits because the costs of private benefits are not fully internalized. On the contrary, if it is less than 1 , it is

\footnotetext{
${ }^{1}$ There has been some recent work on how to separate voting rights from cash flow rights in more subtle ways than e.g. having multiple classes of common stock. See Hu and Black [2007] for more on this decoupling of economic and voting ownership.
} 
considered to reflect a preference for security benefits.

Because I am concerned with blockholders' potential expropriation, I use the ShapleyShubik voting power index. Using the Shapley-Shubik index is analogous to stating that if a coalition is large enough to win, it should avoid accepting additional shareholders, since these new shareholders will demand a share of the payoff available to the winning coalition without contributing essential votes to the coalition. In other words, a smaller winning coalition is preferable because it has a larger group of shareholders from whom to expropriate (hence the Shapley-Shubik index captures the fundamental idea of the coalition formation effect introduced in Bennedsen and Wolfenzon [2000]).

My results are primarily based on analyses using the transaction premium as the dependent variable. Using data on 212 U.S. transactions, I find that in block transactions, the selling shareholders typically attach more value to private benefits than the buyers. In tender offer transactions, I find that private benefits are insignificant to both sides of the transaction. The sign of the coefficient lends support to the conclusion that the selling shareholders attach more value to private benefits though. As an alternative that considers stock market expectations, I also run the regressions with an abnormal return premium as the dependent variable. Again, the sign of the coefficients lends support to the conclusion that the selling shareholders attach more value to private benefits, but none of them are statistically significant. The insignificance of private benefits in the market's estimate of the premium is somewhat expected given the private nature of private benefits.

Finally, all shareholders are initially assumed to have the same propensity to participate in voting and similar control abilities. Especially inside shareholders may violate this assumption. To address this concern, I re-calculate all shareholders' voting power in two-stage games, where inside shareholders form ex ante coalitions before entering the voting game as a block (Crespi and Renneboog [2003]). I find this to have only a very small effect on the results. Inside shareholders do, however, seem to attach higher value 
to private benefits than other selling shareholders.

I proceed as follows. Section 2 presents the framework of analysis. This includes sub-sections on block transactions and three different types of tender offer transactions. Section 3 describes data sources, construction of variables, and presents descriptive statistics of these variables. Section 4 presents my results in more detail, and section 5 concludes.

\section{Framework of analysis}

Consider a firm with an incumbent blockholder owning a fraction $w_{1}$ of the voting rights, the remaining $\left(1-w_{1}\right)$ being dispersed among many small shareholders. The firm is approached by a potential investor. Under the incumbent blockholder, security benefits are $y_{S}$ and private benefits are $z_{S}$. Under the potential investor, security benefits are $y_{B}$ and private benefits are $z_{B} \cdot{ }^{2}$ It is a necessary and sufficient condition for a control transfer that the sum of expected security benefits and expected private benefits under the buyer's control is equal to or larger than the sum under the seller. Finally, there are no restrictions on the seller's prior share of voting rights, the share of voting rights sought, or the structure of the bid.

Whether or not a control transfer will take place may depend on whether, and to what extent, the law provides minority shareholders with rights to participate in (or otherwise benefit from) the transaction. In the US, the general rule has been that minority shareholders do not have a right to participate (Bebchuk [1994]).

\footnotetext{
${ }^{2}$ In the spirit of Grossman and Hart [1988] and Harris and Raviv [1988], this is a two-sided private benefits framework.
} 


\section{$2.1 \quad$ Block transactions}

In absence of a mandatory bid rule in the company law, the seller and the buyer are not obliged to let the small shareholders participate in the control transaction, and control can be transferred through a privately negotiated block transaction on mutually agreeable terms. Hence, a necessary and sufficient condition for a control transfer is that the block has a higher value under the buyer's control than under the seller's, or formally that $w_{1} y_{B}+z_{B} \geq w_{1} y_{S}+z_{S}$ holds. This is the result from Bebchuk [1994] and Burkart and Panunzi [2003]. Both assume that the block provides effective control of the firm and thus that all private benefits accrue to the block.

The assumption that private benefits accrue only to the blockholder is common in the corporate governance literature; it comes from the persistent view that ownership is dispersed. However, even in the US where publicly traded firms stand out as having more widely dispersed ownership structures, many firms have significant blockholders (Gadhoum et al. [2005] and Dlugosz et al. [2006]).

Drawing on Zwiebel [1995], I assume that private benefits do not accrue only to the controlling shareholder, that private benefits are in fact divisible, and that they are allocated to each member of the controlling coalition according to voting power. In this case, the necessary and sufficient condition is that $w_{1} y_{B}+\phi_{1} z_{B} \geq w_{1} y_{S}+\phi_{1} z_{S}$, or, equivalently, that

$$
w_{1}\left(y_{B}-y_{S}\right)+\phi_{1}\left(z_{B}-z_{S}\right) \geq 0
$$

where $\phi_{1}$ is the voting power of the block, and thus the expected share of private benefits going to the block. It is important to recognize that the size of the block and thus the voting power is constant. Private benefits of the buyer and seller differ because of different expectations to the fixed payoff available to the winning coalition. ${ }^{3}$ If the blockholder's

\footnotetext{
${ }^{3}$ Sources of payoff include self-dealing such as transfer pricing, self-served financial transactions such as
} 
fraction of the voting rights exceeds a simple majority of $50 \%$ plus one vote, $\phi_{1}=1$ and I get the same result as Bebchuk [1994] and Burkart and Panunzi [2003]. Equation (1) is only different when minority blocks are traded. The significance of private benefits relative to security benefits is then less than what it would otherwise be.

My main interest in this paper is exactly the significance of private benefits relative to security benefits in corporate control transactions. The transaction price, and thus the transaction premium, is a solution to the bargaining game between the seller and the buyer; the lower bound being the seller's valuation of the block, and the upper bound being the buyer's valuation of the block. It does not take into account that a control transfer might cause negative externalities, i.e. that it might be detrimental to the small shareholders; it depends only on the two parties' expected security benefits and private benefits. The buyer might be a less efficient monitor of the firm with less value attached to security benefits, but with sufficiently large private benefits, the control transfer may happen anyway. Asymmetric information between the seller and the buyer should be reflected in the transaction price.

Now, divide equation (1) by $w_{1}$ and define the block's relative voting power as $\Phi_{1} \equiv$ $\phi_{1} / w_{1}$. By rearranging, the necessary and sufficient condition for a control transfer becomes

$$
y_{B}-y_{S} \geq \Phi_{1}\left(z_{S}-z_{B}\right)
$$

If the buyer is indeed a less efficient monitor of the firm with high private benefits, then both sides of the inequality in equation (2) are negative. A transaction would require the difference in security benefits to be less than the difference in private benefits, which depends directly on $\Phi_{1}$. Notice that $\Phi_{1}$ tells us something about the marginal values. If directed equity issuance, or, if the large shareholder is also the firm's management, excessive compensation (Djankov et al. [2005]). 
it is less than 1, the block's marginal value of security benefits is larger than the marginal value of private benefits. If it is larger than 1 , the marginal value of private benefits is larger than the marginal value of security benefits.

Consider the situation in which $\Phi_{1}<1$ and $z_{S}<z_{B}$. The buyer can then afford a decrease in security benefits, i.e. $y_{B}<y_{S}$. However, because the marginal value of security benefits is higher than the marginal value of private benefits, the buyer cannot afford a one-to-one decrease. If $z_{S}>z_{B}$, the buyer can use security benefits to compensate the seller for giving up large (larger) private benefits. In order for the transaction to succeed, the seller has to earn more security benefits, i.e. $y_{B}>y_{S}$. But because of the marginal effects, this can be done with a difference in differences less than one-to-one.

Now, consider the situation in which $\Phi_{1}>1$ and $z_{S}<z_{B}$. In this situation, the buyer can afford a larger than one-to-one decrease in security benefits, i.e. $y_{B}<<y_{S}$, because the marginal value of private benefits is larger than that of security benefits. Similarly, in the opposite situation in which $z_{S}>z_{B}$, the buyer has to earn more security benefits, i.e. $y_{B}>>y_{S}$.

To get an idea of the empirical implications, it is useful to define a benchmark. I assume that the solution to the bargaining game between the seller and the buyer is a Nash equilibrium. In such a Nash equilibrium, the two parties divide the surplus evenly. From the comparative analysis, we see that the difference between $y_{B}$ and $y_{S}$ becomes larger when $\Phi_{1}$ increases, which means that the total surplus from the transaction increases when the buyer's private benefits are larger than the seller's private benefits, and that it decreases when the seller's private benefits are larger than the buyer's private benefits.

Proposition 1 In terms of the relationship between the transaction premium and the block's relative voting power, we would thus expect a positive relation when $z_{S}<z_{B}$ and a negative relation when $z_{S}>z_{B}$. 


\subsection{Tender offers}

Most of the ideas from block transactions carries over to tender offers. Nonetheless, tender offers are public offers made to all shareholders, and I have to change the condition in equation (1) to capture this. Tender decisions are made by all shareholders where each shareholder individually evaluates the necessary condition given its own parameter values for $w$ and $\phi$. A control transfer now requires the buyer to offer a price that the blockholder, the small shareholders or both favor. This price is non-negotiable so there is no bargaining game between the seller and the buyer. How the surplus is divided depends solely on the buyer through his or her choice of price, and therefore the transaction premium is not a function of the relative power per se. However, since all shareholders, due to their nonatomistic characterization, are pivotal with some positive probability, they individually compare the value under the buyer not to the bid price (contrary to the Grossman and Hart [1980] case with atomistic shareholders and free-riding) but to the current market value when deciding whether to tender their shares. Private benefits increase the price that the buyer has to offer to succeed, and the transaction premium is a function of the relative power after all.

\subsubsection{The blockholder}

For the blockholder, my expectation does not change. The necessary and sufficient condition is exactly the same as in equation (2), and the comparative analysis are as described in section 2.1 .

Proposition 2 In terms of the relationship between the transaction premium and the block's relative voting power, we would thus expect a positive relation when $z_{S}<z_{B}$ and a negative relation when $z_{S}>z_{B}$. 


\subsubsection{The small shareholders}

For the small shareholders, the necessary and sufficient condition for a control transfer is that

$$
\sum_{i=2}^{n} w_{i}\left(y_{B}-y_{S}\right)+\sum_{i=2}^{n} \phi_{i}\left(z_{B}-z_{S}\right) \geq 0
$$

or, equivalently, that

$$
y_{B}-y_{S} \geq \Phi_{S}\left(z_{S}-z_{B}\right)
$$

where $\Phi_{S} \equiv \sum_{i=2}^{n} \phi_{i} / \sum_{i=2}^{n} w_{i}$ is the relative voting power of all the small shareholders. For this definition of relative voting power to be testable, I have to assume that the small shareholders are identical and homogeneous in their decision to tender. It is possible to have negative externalities, although it is less likely that the small shareholders expropriate the blockholder than the other way around. Notice that equation (3) is the same as $\left(1-w_{1}\right)\left(y_{B}-y_{S}\right)+\left(1-\phi_{1}\right)\left(z_{B}-z_{S}\right) \geq 0$, which shows that the necessary condition for the small shareholders and hence their decision to tender, is directly related to that of the blockholder. The more powerful the blockholder is, the less it takes to make the small shareholders tender their shares and vice versa.

Once again, consider the situation where the buyer is a less efficient monitor of the firm with high private benefits. The idea from section 2.1 carries over. Both sides of the inequality in equation (3) are negative and a transaction would require the difference in expected security benefits to be less than the difference in expected private benefits, which in this case depends on $\Phi_{S}$ instead of $\Phi_{1}$. Replacing the relative voting power of the blockholder with the relative voting power of all the small shareholders, the comparative analysis are the same as in section 2.1 as well.

Proposition 3 In terms of the relationship between the transaction premium and the 
small shareholders' relative voting power, we would thus expect a positive relation when $z_{S}<z_{B}$ and a negative relation when $z_{S}>z_{B}$.

Despite the opposing behavior of the blockholder and the small shareholders in their decision to tender, I thus come to expect the same general result. Regardless of whoever tenders, we expect the transaction premium to increase in relative voting power and the sign of the parameter estimate to state whether the seller or the buyer has more value attached to private benefits. Next, I analyze the intersection of these two cases to see if this result holds when both groups tender at the same time.

\subsubsection{The blockholder and the small shareholders}

A control transfer that at the same time is valuable for both the blockholder and the small shareholders requires that

$$
y_{B}-y_{S} \geq \max \left\{\left|\Phi_{1}\left(z_{S}-z_{B}\right)\right| ;\left|\Phi_{S}\left(z_{S}-z_{B}\right)\right|\right\}
$$

In this case, a transaction depends on the relative voting power that maximizes the right hand side of equation (4). If the necessary condition is satisfied, there can be no negative externalities. In fact, the max function aligns the interests of the two groups of shareholders in terms of transaction price and thus transaction premium. The source of this interdependence is the buyer's demand for shares and pre-bid consideration of private benefits. Unfortunately, the max function causes some ambiguity in the comparative analysis, since, by construction, the relative voting power of one group of shareholders cannot increase without a decrease in the relative voting power of another group of shareholders.

Consider the situation in which $\Phi_{1}<1, \Phi_{S}>1$, and $z_{S}<z_{B}$. Because of larger private benefits, the buyer can afford a decrease in security benefits, i.e. $y_{B}<y_{S}$, and, in this situation, the maximum decrease depends on the small shareholders, who have the 
largest relative voting power. Since their marginal value of private benefits is larger than that of security benefits, the buyer can afford a larger than one-to-one decrease in security benefits, i.e. $y_{B}<<y_{S}$. If $z_{S}>z_{B}$, the buyer must use security benefits to compensate the seller for giving up larger private benefits, i.e. $y_{B}>y_{S}$, and because of the marginal effects, a transfer of control requires that the buyer expects to earn more security benefits, i.e. $y_{B}>>y_{S}$.

Now, consider the situation in which $\Phi_{1}>1, \Phi_{S}<1$, and $z_{S}<z_{B}$. The maximum decrease in security benefits depends on the blockholder, and because the marginal value of private benefits is larger than the marginal value of security benefits, the buyer can, as before, afford a larger than one-to-one decrease, i.e. $y_{B}<<y_{S}$. However, whether the buyer can afford an even larger decrease in security benefits depends on how much $\Phi_{S}$ drops below 1 when $\Phi_{1}$ raises above 1 . This is where the comparative analysis become ambiguous. If the difference between $\Phi_{1}$ and $\Phi_{S}$ is larger than the prior difference between $\Phi_{S}$ and $\Phi_{1}$, then $y_{B}<<<y_{S}$. If the difference between $\Phi_{1}$ and $\Phi_{S}$ is smaller than the prior difference between $\Phi_{S}$ and $\Phi_{1}$, the difference between $y_{B}$ and $y_{S}$ also becomes smaller. A similar argument can be made in the opposite situation in which $z_{S}>z_{B}$. In either case, the difference between $y_{B}$ and $y_{S}$ in the intersection is at least as large as the difference between $y_{B}$ and $y_{S}$ in the separate cases (this is because of the max function).

The ambiguity disappears if I use the absolute difference between $\Phi_{1}$ and $\Phi_{S}$ instead of $\Phi_{1}$ to derive the empirical expectation. As this difference increases, the difference between $y_{B}$ and $y_{S}$ also increases. In a Nash equilibrium, an increase in the absolute difference between $\Phi_{1}$ and $\Phi_{S}$ results in a higher transaction price and thus a higher transaction premium. The larger the difference is the higher is the valuation of private benefits (by either the blockholder or the small shareholders) and the price that the buyer is willing to pay.

Proposition 4 In terms of the relationship between the transaction premium and the 
absolute difference between the blockholder's relative voting power and the small shareholders' relative voting power, we would thus expect a positive relation when $z_{S}<z_{B}$ and a negative relation when $z_{S}>z_{B}$.

\section{Data and sample construction}

My transaction data come from the SDC Platinum Mergers and Acquisitions database. I use data on transactions for majorities, remaining interests, tender offers, and minority stake purchases involving U.S. targets. I require that transactions are completed, and that values necessary for computing the transaction premium are available. I also require that target firms' ticker symbols can be matched with ownership data from Dlugosz et al. [2006], who have recorded the distribution of voting rights in a large sample of large U.S. firms with only one class of common stock in the period from 1996 to $2001 .^{4}$ These data are especially suitable for this paper because they focus explicitly on both blockholders and voting rights.

For a match to enter the sample, I furthermore require that target firms' ownership structures are known at some date less than 1 year prior to the transaction. The fact that the ownership data are not from the exact same date does not cause a serious problem, because ownership structures tend to be stable over time (Bebchuk and Roe [1999]). One caveat should be mentioned though: prior to corporate control transfers, ownership structures may be more unstable because of a potential investor's creeping accumulation of shares.

To control for idiosyncratic characteristics, I collect accounting variables for each target firm from Compustat Industrial Annual. Finally, I require that target firms' ticker symbols

\footnotetext{
${ }^{4}$ Dlugosz et al. [2006] document problems with currently available data, propose a consistent set of solutions to these problems, and make a "clean" database freely available. This database can be downloaded from http://finance.wharton.upenn.edu/ ${ }^{\sim}$ metrick/data.htm.
} 
can be matched with daily stock price data from CRSP and corporate governance data from Gompers et al. [2003]. The balanced sample is reduced to 212 transactions. $^{5}$

\subsection{Variables}

\subsubsection{Transaction premium}

My left hand side variable is the transaction premium. I calculate the transaction premium as the buyer's offer as a percentage of the target firm's market value of equity four weeks prior to the announcement. SDC offers several different sources for such a premium computation. The value of the buyer's offer is calculated as a combined premium estimate similar to that described in detail in Officer [2003]. In short, this procedure integrates a price premium based on the final offer, a component premium based on, in order of availability, the aggregate amount of each form of payment offered to the seller, and a price premium based on the initial offer.

Corporate control transfers qualify for event analysis, and although this methodology mixes the market's estimate of the premium with the likelihood of the transaction going through (Officer [2003]), abnormal return-based measures of transaction premiums are common in the literature. Therefore, I calculate the Schwert [2000] abnormal return premium as an alternative measure of the transaction premium as well. This is defined as the sum of abnormal returns of the target firm's shares in a period from 63 days before to 126 days after the announcement date. To calculate abnormal return I use a CRSP value-weighted market model with parameters estimated using daily returns for the year ending on day 64 before the announcement date. Regression results do not change when

\footnotetext{
${ }^{5}$ The Dlugosz et al. [2006] database use the Investor Responsibility Research Center (IRRC) sample as a starting point. This universe covers about 1,300 single-classed firms per year. The IRRC universe is drawn from the Standard \& Poor's 500 as well as the annual lists of the largest firms in the publications of Fortune, Forbes, and Businessweek. The small intersection between transaction data comprised mainly by small and medium sized firms and ownership data comprise mainly by large firms explains the number observations.
} 
the abnormal return premium is calculated over post transaction days only.

\subsubsection{Relative voting power}

My key right hand side variable is the relative voting power, which is defined as voting power divided by voting weight. My choice of power index is motivated by the notion of power as the expected relative share of benefits available to the controlling coalition of shareholders (Felsenthal and Machover [1998]). The Shapley and Shubik [1954] power index supports this notion. It captures the idea that a small controlling coalition has a larger group of outside shareholders (outside the controlling coalition) to extract private benefits from. We know that a selling shareholder with private benefits is likely to accept an offer with negative externalities, and since the marginal value of private benefits depends directly on voting power, this solution suits my purpose well.

Formally, shareholder $i$ 's power index value is

$$
\phi_{i}=\sum_{S \subseteq N, i \in S} \frac{(s-1) !(n-s) !}{n !}[v(S)-v(S \backslash\{i\})],
$$

where $s$ is the number of shareholders in the controlling coalition $S$, and $n$ is the number of shareholders in the firm. The characteristic function $v$ indicates the value of $S$. The power index satisfies the condition for a relative power index, as the shareholders' power index values add up to 1 . Calculations are carried out using a generating function algorithm with a simple majority requirement.

Calculations of voting power and relative voting power require a complete account of the distribution of votes, but the available ownership structure data only include those shareholders with at least $5 \%$ of the voting rights (due to disclosure requirements). Consequently, I have to make an assumption about the small shareholders. Two procedures can be found in the literature. One assumes that the unobserved shareholders are not influential, and the other assumes that they are influential with some positive probability. 
The latter is equivalent to my assumption about non-atomistic shareholders, in which case I should use a finite representation such as the one proposed by Guedes and Loureiro [2002] to approximate the actual distribution of votes. It simply assumes that each small shareholder holds $1 \%$ of the votes and then adds shareholders until the joint votes of all shareholders add up to $100 \%$.

\subsubsection{Relative voting power in a two-stage game}

The power index value in equation (5) assumes that each coalition is formed with equal probability. It is possible that the relative voting power is better described by a twostage voting game, since it may be easier for specific classes of shareholders to form ex ante coalitions before entering the voting game as a block (Crespi and Renneboog [2003]). Inside shareholders may have similar private benefits, and they may combine their ownership stakes to a substantial block of voting power to extract private benefits from outside shareholders (see Stulz [1988] for a theoretical model, and McConnell and Servaes [1990] for empirical support). To test whether this is the case, I re-calculate the relative voting power for all shareholders in a two-stage voting game with insiders forming ex ante coalitions.

The ownership structure data classify those shareholders with at least $5 \%$ of the voting rights into five categories. These are officer, director, affiliated entity, employee share ownership plan, and outside blockholder. Although employees' objectives in many cases differ from those of officers and directors, trustees of employee share ownership plans are considered insiders. In accordance with Schedule 14a of the Security Exchange Act of 1934, the proxy statements and therefore also the data contain insider ownership below $5 \%$. I define the block of inside shareholders as 1 minus the sum of outside blockholders and let this block enter the voting game with the remaining outside blockholders and small shareholders. Under Section 12 of the Act, anyone who own more than $10 \%$ of the 
shares is considered an insider. This consideration is not, however, used in the data. A blockholder is only considered an insider if she belongs to one of the first four categories.

\subsubsection{Controls}

There are a number of characteristics about the transaction, the seller, and the buyer that are likely to be correlated with the transaction premium, and that I should control for in the regression models. These control variables are taken from papers explaining the transaction premium, including Schwert [2000], Officer [2003], Nicodano and Sembenelli [2004], Gaspar et al. [2005], Burkart and Panunzi [2006], amongst others. This literature finds that transaction premiums tend to be higher when there are competing bidders, when the target management is hostile towards the buyer, and when the mode of payment is cash. Due to relatively weak competition and almost no hostility, and to maintain as many degrees of freedom as possible, I disregard the first two control variables. Since cash and equity are considered substitute modes of payment, the positive correlation between market valuation and equity (Andrade et al. [2001], Holmstrom and Kaplan [2001]) might affect the effect of cash. I therefore construct a market-timing dummy variable equal to one in years with increasing market values and zero otherwise, and include the interaction between this variable and cash as the mode of payment as an additional control variable. Qualitatively, it does not matter whether I use all cash or any cash. This literature also finds that premiums tend to be lower when the buyer holds a toehold in the target, when the target is large, when the target is profitable, and when that target leverage is ambiguous since it constrains managerial discretion but also increases size.

In addition, I construct a dummy variable for cross-border transactions, a dummy variable for two-digit Standard Industrial Classification code intra-industry transactions, and a dummy variable for the buyers' post-transaction ownership stake. Transactions with buyers from countries with less investor protection are likely to yield a higher price, 
and hence a higher transaction premium, because they are better able to expropriate corporate resources (Dyck and Zingales [2004]). Consequently, I construct a measure of the difference in the legal protection variable (based on the La Porta et al. [1998] measure of antidirector rights), and include the interaction between this variable and the crossborder dummy as a control variable. The reason for including the intra-industry variable is that such a transaction reduces product market competition and thus increases the buyer's ability to expropriate corporate resources. The post transaction variable is supposed to capture that a majority stake, regardless of size, qualifies for outright control, and hence larger private benefits. The voting power calculations do capture this non-linearity, but it is lost in the normalization by voting weight. Finally, I also include the target firm's Governance Index as a proxy for the balance of power between shareholders and managers based on provisions that restrict shareholders' rights. I can use this to control for potential expropriation by insiders prior to their ex ante coalition formation in the two-stage game.

\subsection{Descriptive statistics}

Table 1 presents descriptive statistics for variables used in this study. For the transaction premium and all accounting variables, I exclude observations more than $2 \times \mathrm{IQR}$ (interquartile-range) away from the first and third quartiles, respectively. My results are not qualitatively sensitive to the choice of another reasonable multiple, although the increase in variance reduces the significance of parameter estimates. I also exclude two firms with negative common equity. Shareholders in firms in such deep financial distress are in a weak bargaining position, and this is likely to dominate the outcome.

As a check for robustness of the transaction premium, I follow Officer [2003] and exclude observations below zero and above two. In doing so, I get significantly higher mean and median estimates. Is it meaningful then to winsorize especially observations below zero in this study? A negative transaction premium is realized in 32 transactions 
after removing outliers. If the market value of the firm under the incumbent blockholder is overvalued, $z_{S}$ is not sustainable, and, in that case, the seller is likely to agree on a price below the current market value. Another explanation could be that the seller, by selling only a fraction of the initial stake, internalizes less of the costs of private benefits. ${ }^{6}$ This is a trade-off between the loss of private benefits from owning a smaller fraction of the shares and the gain from transferring some of the costs to other shareholders. If there is a net gain, the seller is also likely to agree on a price below the current market value. I choose to include observations below zero. The average transaction premium received by the selling shareholders is then $27.20 \%$. This is very close to the average abnormal return premium, which is $25.08 \%$, and suggests that the stock market considers the control transfer efficient, i.e. expects higher future security benefits.

The average largest shareholder has $14.95 \%$ of the voting rights, and the average firm has $72.71 \%$ of the shares widely dispersed among small shareholders. The remaining shares are held by a number of inferior blockholders, the average number of blockholders (not tabulated) being 2.66. Although the analytical framework is set up with only one blockholder, this does not cause a problem. Inferior blockholders just reduce the power and hence the private benefits of the largest shareholder. In other words, inferior blockholders serve as monitors of the largest shareholder (Bennedsen and Wolfenzon [2000]), with the exception of inside shareholders in the two-stage game.

The relative voting power of the largest shareholder in the base case one-stage game is 1.15. For the small shareholders it is 0.93 . Remember how the relative voting power can tell us something about the marginal values of security benefits and private benefits, respectively. If the relative voting power is smaller than 1 , as is the case for the small shareholders, the marginal value of security benefits is larger than the marginal value of

\footnotetext{
${ }^{6}$ The cost of private benefits is due to the fact that the incumbent block holder fails to internalize the negative impact that a control transfer has on the $(1-w)$ widely held shares, and the fact that private benefits are extracted (in part) at the expense of security benefits (Burkart and Panunzi [2003]).
} 
private benefits. On the other hand, if it is larger than 1, as is the case for the largest shareholder, the marginal value of private benefits is larger than the marginal value of security benefits. Since we do not have an explicit model for the relation between voting power and private benefits, I cannot make further inferences about the deviation from 1 .

Yet, these relative voting power values may be misleading as they assume that every shareholder has a similar propensity to participate in voting coalitions and similar control abilities. The empirical evidence that powerful inside shareholders entrench outside shareholders motivates the re-calculation of relative voting power in a two-stage voting game with insiders forming ex ante coalitions. Table 1 shows that the average effect of this is small. The relative voting power for the largest shareholder, whether this is a single shareholder or a group of inside shareholders, increases to 1.17. There is a corresponding decrease in the relative voting power of the small shareholders.

Tender offers account for about $16 \%$ of the sample transactions. Cash is used as a mode of payment in more than $70 \%$ of the transactions (not tabulated), and the average percentage of total consideration paid in cash is 90 . In $25 \%$ of the target firms, the buyer owned shares in the firm six months prior to the transaction. Note that if the buyer qua the toehold is the largest shareholder, the analytical framework does not make sense, and the observation should be removed from the data set. In $58 \%$ of the transaction, the buyer owns the majority of voting rights after the transaction. In 116 firms, the buyer owns all voting rights after the transaction (not tabulated).

About $14 \%$ of the transactions are cross-border with a non-U.S. entity buying into a U.S. firm. While this means that most buyers submit to higher investor protection, buyers from countries with less investor protection are nonetheless better able to expropriate corporate resources. Therefore, I calculate the difference in legal protection and find it to be 2.13, which suggests that there is scope for significant private benefits for the buyer. A similar argument can be made for transactions within the same industry, i.e. buyers 
from the same industry are better able to expropriate corporate resources in the target firm. About $47 \%$ of the transactions are intra-industry. In the next section, I will look at the effect of buying into high private benefit industries.

So far, I have postponed the distinction between block transactions and tender offer transactions, also presented in table 1. First, note that the transaction premium as well as the abnormal return premium is significantly higher in tender offers than in block transactions. This is because the buyer must hand over all improvements in security benefits to the incumbent shareholders to make them tender; the buyer's offered price must match the post-transaction share value (Grossman and Hart [1980]). However, because the buyer is not compensated ex ante for abstaining from extracting private benefits ex post, and because of the tendering shareholders' non-atomistic characterization, such gains do exist in tender offers despite the absence of private negotiations. While this post transaction moral hazard and associated inefficiency is troublesome, private benefits are one of the suggestions in Grossman and Hart [1980] to prevent failure of value increasing (tender offer) bids.

Second, note that the wedge in relative voting power between the largest shareholder and the small shareholders is larger in tender offers than in block transactions. Target firms in completed tender offer transactions apparently have more dispersed ownership structures, which is not surprising though. However, because there is at least one blockholder in each sample firm, equation (4) applies as here the max function aligns the interest of the two groups of shareholders in terms of transaction price. In the case of tender offers, the wedge is therefore of no concern in regard to potential extraction of private benefits by the large shareholder at the expense of the small shareholders.

Third, note that a tender offer more frequently results in the buyer having a posttransaction majority; that negotiations of block transactions tend to happen between U.S. entities (only 11\% are cross-border); that target firms in tender offer transactions 
tend to have better corporate governance (although the difference is negligible); and that intra-industry transactions, which are a type of transaction in which we would expect relatively high private benefits, are less frequent in block transactions.

\section{Results}

In this section, I present the empirical results of private benefits' significance relative to security benefits in corporate control transactions. My conjectures are formulated in propositions 1 to 4 . In the tender offer transactions in my data set, however, I do not know who tenders and who does not tender. In the empirical model I am therefore not able to take propositions 2 and 3 into account.

The main model is an ordinary least squares model that includes data on 212 transactions. The data is cross-sectional in nature; although it spans a 6-year period from 1996 to 2001, each firm only enters the sample once. On the basis of the discussion in the previous section, the following model is estimated.

$$
\text { Premium }_{i}=\alpha_{0, i}+\beta_{1} \Phi_{1, i} \text { Block }_{i}+\beta_{2}\left|\Phi_{1, i}-\Phi_{S, i}\right| \text { Tender }_{i}+\sum_{k} \beta_{k} \text { Control }_{i, k}+\varepsilon_{i} .
$$

The model has been checked for collinearities among the regressor variables (using the variance inflation factor) without causing any changes. The model is estimated for both premium variables with one-stage and two-stage games, respectively. Tables 2 and 3 report parameter estimates and White consistent t-statistics.

To recap, voting rights are the vehicle for private benefits, and voting power measures the influence carried by voting rights. If a share of voting rights provides more influence than the investment warrants pro rate (due to the specific structure of ownership), the shareholder has a marginal preference for private benefits (because all associated costs are 
not fully internalized). In that case, I conjecture that there is a positive relation between the shareholder's relative voting power (valuation of private benefits) and the transaction price. If the model returns a negative estimate, I conjecture that the shareholder has a marginal preference for security benefits and values the transaction for security benefits instead of private benefits.

In table 2, with transaction premium as the dependent variable, the negative and statistically significant coefficient of the largest shareholder's relative voting power lends support to the conclusion that, in block transactions, the selling shareholders attach more value to private benefits than the buyers. This conclusion is reinforced by looking at the interaction between intra-industry transactions and private benefit industries; ${ }^{7}$ it shows that investors buying into these industries need to compensate the selling shareholders for giving up high private benefits. The coefficient is positive and significant. The coefficient of intra-industry is also positive but not of the same magnitude and not significant.

The coefficient of the absolute difference between the blockholder's relative voting power and the small shareholders' relative voting power is negative but not significantly different from zero. The reason for this insignificance of private benefits in tender offers is unclear. On the one hand, private benefits could be decisive for the buyer in making a successful tender offer in which all improvements in security benefits have to go to the selling shareholders in order to prevent them from free riding. There are other ways to solve the free rider problem though: for example, buying a stake prior to the tender offer. However, the coefficient of toehold turns out to be insignificant as well. On the other hand, the selling shareholders, due to the dispersed ownership structure (and hence low relative voting power) that typically characterizes firms that receive tender offers, do not attach notable value to private benefits. Besides, voting power does not translate into

\footnotetext{
${ }^{7}$ Following Demsetz and Lehn [1985] and Bennedsen and Nielsen [2006], I expect private benefits to be higher in certain industries. I classify media (SIC major groups 27 and 78), advertising (73), and sport and entertainment (79) as industries with high private benefits.
} 
bargaining power that leads to a higher premium. Finally, the high amount of shares tendered (remember that the empirical testing of the framework only considers those tender offers that at the same time are valuable to both the blockholder and the small shareholders) results in a high post-transaction voting stake for the buyer (the posttransaction dummy variable is one in $82 \%$ of the tender offer transactions relative to $53 \%$ in block transactions), which means that more costs of private benefits are internalized.

Pushing the argument that private benefits are important further, I run regressions in which I assume that inside shareholders form coalitions before entering the voting game with outside shareholders (two-stage game). Panel B presents the results. It turns out to have only a small qualitative effect on the results. While the number of shareholders that participate in the voting game decreases, the increase in inside shareholders' voting stake is not large enough to cause any significant changes in the effect of the relative voting power (the increase in relative voting power is from 1.15 to 1.17 , cf. table 1 ). The coefficient of the largest shareholder's relative voting power is slightly lower at -0.20 , indicating that inside shareholders attach more value to private benefits than outside shareholders.

The coefficient of the Governance Index lends support to this conclusion. It is supposed to control for potential entrenchment by insiders prior to their ex ante coalition formation in the two-stage game. The parameter estimate is zero. Again, the reason could be that inside shareholders are infrequent and relatively small in this sample. Another reason could be that the observed (outside) ownership structure is a market response to the corporate governance environment that effectively remove any significant inside shareholder private benefits.

Only a few control variables have significant parameter estimates. I have already mentioned the positive effect of buying into private benefit industries. The other significant control variable is the post-transaction majority variable. A majority stake qualifies for 
outright control and potentially larger private benefits. Given the relative voting power results, buyers however do not attach as much value to private benefits as sellers. In other words, it is the value that they attach to security benefits that makes the transaction succeed. The positive coefficient therefore lends support to the conclusion that the buyer is willing to pay a higher premium for obtaining a controlling stake (regardless of whether a majority stake is transacted or the transacted shares together with the buyer's toehold constitute a majority) in order to have the necessary power to make improvements in security benefits.

In table 3 panel $\mathrm{A}$, with abnormal return premium as the dependent variable, all variables except private benefit industry have insignificant parameter estimates. The event study analysis mixes the market's estimate of the premium with the likelihood of the transaction going through. Clearly, the market's estimate of the premium does not take into consideration the private benefits from the influence that comes with the number of shares transacted. This is not surprising given the opaque nature of private benefits. If the target firm belongs to a private benefit industry, it does, however, take this into consideration. The coefficient is positive and significant. Again, this can be interpreted as compensation to the selling shareholders for surrendering voting control and giving up high private benefits. The coefficient is also considerably higher than the corresponding coefficient in table 2 , where the dependent variable is the transaction premium.

The effect of inside shareholders forming coalitions before entering the voting game with outside shareholders (two-stage game in panel B) does not change this result. Size and profitability become significant control variables; otherwise no parameter estimates are qualitatively different. 


\section{Conclusion}

This paper contributes to the literature on dynamic allocation of corporate control by presenting an analytical framework from which it can be inferred whether sellers or buyers value private benefits highest. I am thus able to suggest an answer to the question: Are blocks of shares traded because the buyer is a more efficient monitor with high security benefits, or because the buyer has high private benefits from the control rights that come with the shares?

The empirical results are based on a U.S. data set covering 179 block transactions and 33 tender offer transactions. For block transactions, with transaction premium as the dependent variable, the answer is that the selling shareholders attach more value to private benefits than the buyers. These transactions are therefore socially efficient in the sense that control is passed to shareholders who value the firms for their security benefits, which all shareholders profit from (positive externalities of control), and not for private benefits, which expropriates other, typically small, shareholders (negative externalities of control).

In tender offer transactions, also with transaction premium as the dependent variable, the answer is that private benefits are insignificant to both sides of the transaction. I put forward two reasons for this. First, tender offer targets typically have a dispersed ownership structure, where each selling shareholder has low relative voting power and hence low private benefits. Second, the high amount of shares tendered (remember that the empirical testing of the framework only considers those tender offers that at the same time are valuable to both the blockholder and the small shareholders) results in a high post-transaction voting stake for the buyer, which means that more costs of private benefits are internalized. Moral hazard is alleviated by the size of the bidder's final holding.

As an alternative measure of the transaction premium, I calculate the abnormal return 
premium. This represents the stock market's valuation of the transaction. I find that the stock market puts a positive premium on the sample transactions. Although this is not confirmed by the regression results, the market therefore expects higher future security benefits. The negative coefficients of relative voting power lend support to this conclusion, but they are not significant. The insignificance of private benefits in the market's estimate of the premium is somewhat expected given the opaque nature of private benefits.

In this paper, voting rights are the vehicle for private benefits. The key assumption is that private benefits are divisible and allocated to each shareholder according to the shareholder's strategic importance in forming controlling coalitions (Shapley and Shubik [1954] voting power). This approach hinges on two assumptions. First, that there are benefits to large shareholders from being in control. Second, that there is a positive probability that such a blockholder will demand marginal votes in order to attain control. I use relative voting power to distinguish between preferences for security benefits and private benefits. If the relative voting power is larger than 1 , it is considered to reflect a preference for private benefits. On the contrary, if it is less than 1 , it is considered to reflect a preference for security benefits.

Finally, all shareholders are assumed to have the same propensity to participate in voting and similar control abilities. Especially inside shareholders may violate this assumption. To address this concern, I re-calculate all shareholders' voting power in two-stage games, where inside shareholders form ex ante coalitions before entering the voting game as a block. I find this to have only a very small effect on the results. Inside shareholders do, however, seem to attach higher value to private benefits (require higher compensations) than other selling shareholders. 


\section{References}

Andrade, G., Mitchell, M. and Stafford, E. [2001], 'New Evidence and Perspectives on Mergers', Journal of Economic Perspectives 15(2), 103-120.

Barclay, M. and Holderness, C. [1989], 'Private Benefits from Control of Public Corporations', Journal of Financial Economics 25, 371-395.

Bebchuk, L. [1994], 'Efficient and Inefficient Sales of Corporate Control', The Quarterly Journal of Economics 109(4), 957-993.

Bebchuk, L. and Roe, M. [1999], 'A Theory of Path Dependence in Corporate Ownership and Governance', Stanford Law Review 52, 127-170.

Bennedsen, M. and Nielsen, K. M. [2006], 'The Principle of Proportional Ownership, Investor Protection and Firm Value in Western Europe', ECGI Finance No. 134.

Bennedsen, M. and Wolfenzon, D. [2000], 'The Balance of Power in Closely Held Corporations', Journal of Financial Economics 58, 113-139.

Burkart, M. and Panunzi, F. [2003], 'Mandatory Bids, Squeeze-Out, Sell-Out and the Dynamics of the Tender Offer Process', ECGI Law No. 10 .

Burkart, M. and Panunzi, F. [2006], 'Takeovers', ECGI Finance No. 118.

Crespi, R. and Renneboog, L. [2003], 'Corporate Monitoring by Shareholder Coalitions in the UK', ECGI Discussion Paper No. 12/2003 .

Demsetz, H. and Lehn, K. [1985], 'The Structure of Corporate Ownership: Causes and Consequences', Journal of Political Economy 93, 1155-1177.

Djankov, S., Porta, R. L., de Silanes, F. L. and Shleifer, A. [2005], 'The Law and Economics of Self-Dealing', NBER Working Paper Series No. 11883. 
Dlugosz, J., Fahlenbrach, R., Gompers, P. and Metrick, A. [2006], 'Large Blocks of Stock: Prevalence, Size, and Measurement', Journal of Corporate Finance 12(3), 594-618.

Dyck, A. and Zingales, L. [2004], 'Private Benefits of Control: An International Comparison', Journal of Finance 59(2), 537-600.

Felsenthal, D. and Machover, M. [1998], The Measurement of Voting Power: Theory and Practice, Problems and Paradoxes, Edward Elgar.

Gadhoum, Y., Lang, L. and Young, L. [2005], 'Who Controls US?', European Financial Management 11(3), 339-363.

Gaspar, J.-M., Massa, M. and Matos, P. [2005], 'Shareholder Investment Horizons and the Market for Corporate Control', Journal of Financial Economics 76, 135-165.

Gompers, P., Ishii, J. and Metrick, A. [2003], 'Corporate Governance and Equity Prices', The Quarterly Journal of Economics 118(1), 107-155.

Grossman, S. and Hart, O. [1980], 'Takeover Bids, the Free Rider Problem, and the Theory of the Corporation', The Bell Journal of Economics 11, 42-64.

Grossman, S. and Hart, O. [1988], 'One Share-One Vote and the Market for Corporate Control', Journal of Financial Economics 20, 175-202.

Guedes, J. and Loureiro, G. [2002], 'Are European Corporations Fleecing Minority Shareholders?', SSRN Working Paper Series .

Harris, M. and Raviv, A. [1988], 'Corporate Control Contests and Capital Structure', Journal of Financial Economics 20, 55-86.

Holmstrom, B. and Kaplan, S. [2001], 'Corporate Governance and Merger Activity in the United States: Making Sense of the 1980s and 1990s', Journal of Economic Perspectives 15, 121-144. 
Hu, H. and Black, B. [2007], 'Hedge funds, insiders, and the decoupling of economic and voting ownership: Empty voting and hidden (morphable) ownership', Journal of Corporate Finance 13, 343-367.

Jensen, M. [1988], 'Takeovers: Their Causes and Consequences', Journal of Economic Perspectives 2, 21-48.

La Porta, R., Lopez de Silanes, F., Shleifer, A. and Vishny, R. [1998], 'Law and Finance', Journal of Political Economy 106(6), 1113-1155.

Lease, R., McConnell, J. and Mikkelson, W. [1983], 'The Market Value of Control in Public-traded Corporations', Journal of Financial Economics 11, 439-471.

Lease, R., McConnell, J. and Mikkelson, W. [1984], 'The market value of differential voting rights in closely held corporations', The Journal of Business 57(4), 443-467.

Manne, H. [1965], 'Mergers and the Market for Corporate Control', Journal of Political Economy 75, 110-126.

McConnell, J. and Servaes, H. [1990], 'Additional Evidence on Equity Ownership and Corporate Value', Journal of Financial Economics 27(2), 595-612.

Mikkelson, W. and Regassa, H. [1991], 'Premiums Paid in Block Transactions', Managerial and Decision Economics 12(6), 511-517.

Nenova, T. [2003], 'The Value of Corporate Voting Rights and Control: A Cross-Country Analysis', Journal of Financial Economics 68, 325-351.

Nicodano, G. and Sembenelli, A. [2004], 'Private Benefits, Block Transaction Premiums and Ownership Structure', International Review of Financial Analysis 13, 227-244.

Officer, M. [2003], 'Termination Fees in Mergers and Acquisitions', Journal of Financial Economics 69, 431-467. 
Schwert, G. [2000], 'Hostility in Takeovers: In the Eyes of the Beholder', The Journal of Finance 55(6), 2599-2640.

Shapley, L. S. and Shubik, M. [1954], 'A Method for Evaluating the Distribution of Power in a Committee System', The American Political Science Review 48(3), 787-792.

Stulz, R. [1988], 'Managerial Control of Voting Rights: Financing Policies and the Market for Corporate Control', Journal of Financial Economics 20, 25-54.

Zingales, L. [1994], 'The Value of the Voting Right: A Study of the Milan Stock Exchange Experience', The Review of Financial Studies 7(1), 125-148.

Zwiebel, J. [1995], 'Block Investment and Partial Benefits of Corporate Control', Review of Economic Studies 62, 161-185. 


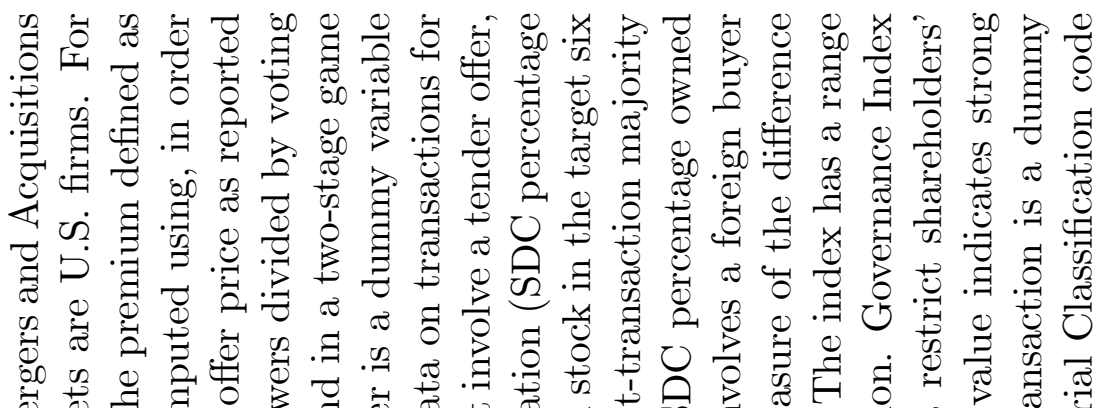

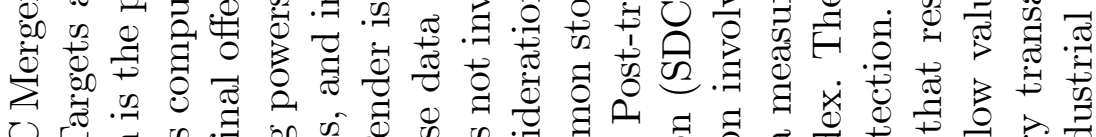

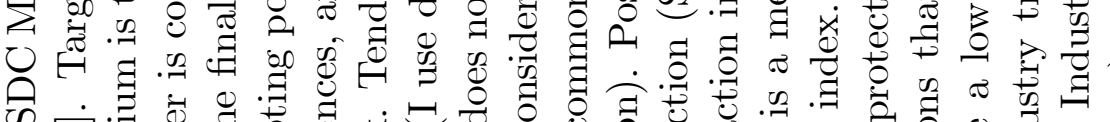

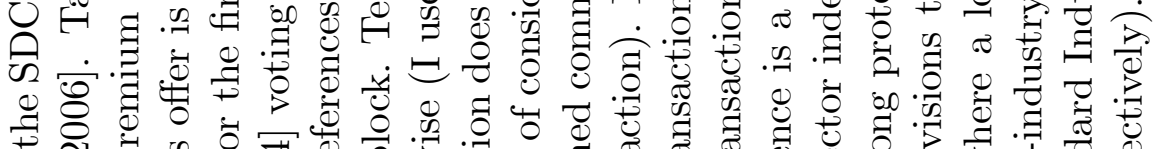

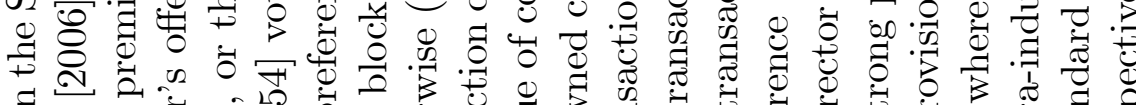

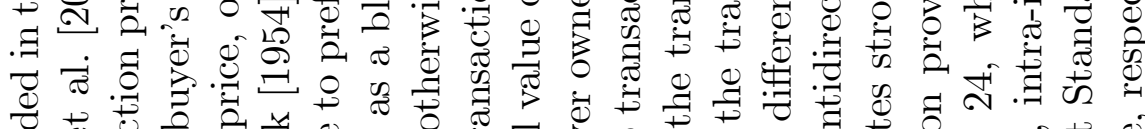

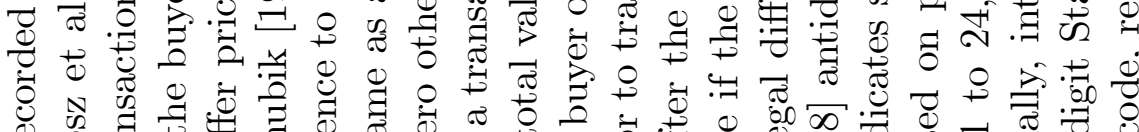
8

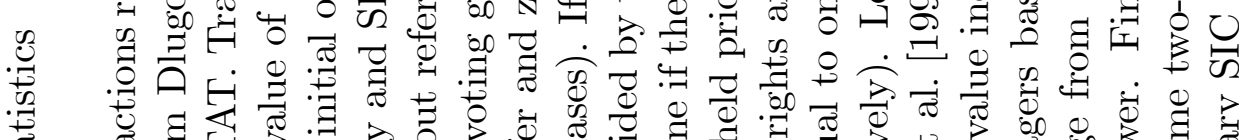

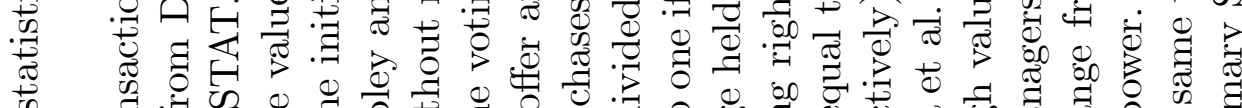

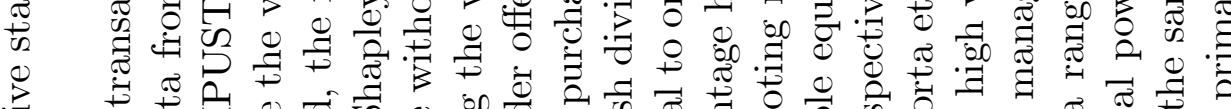

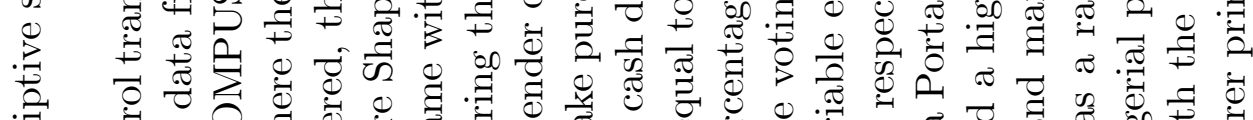

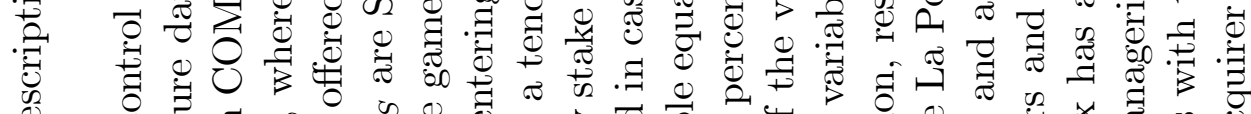
政 8

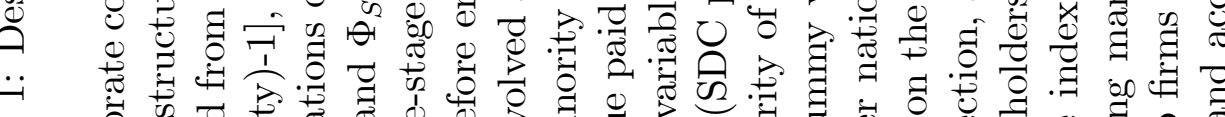

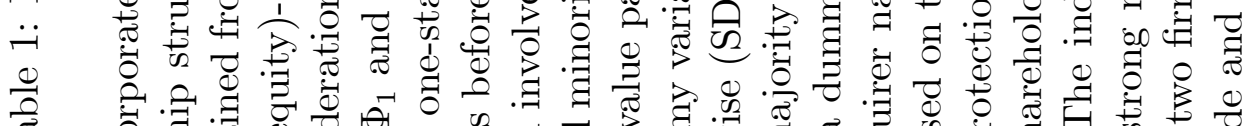

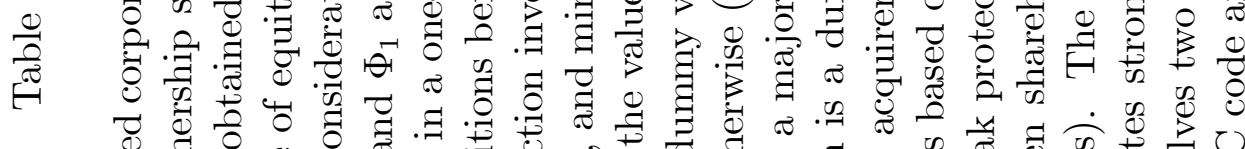

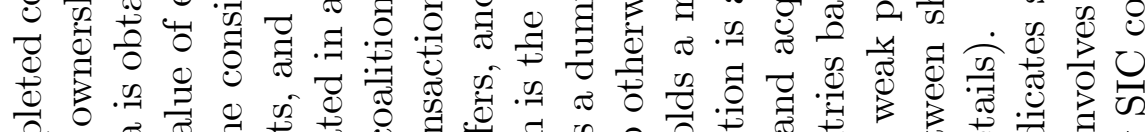

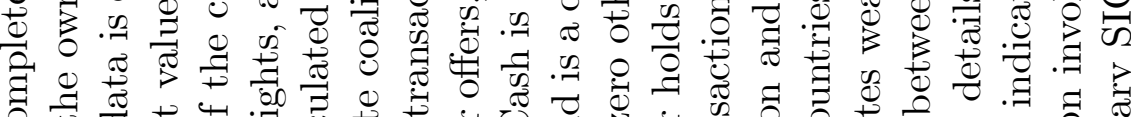
8.

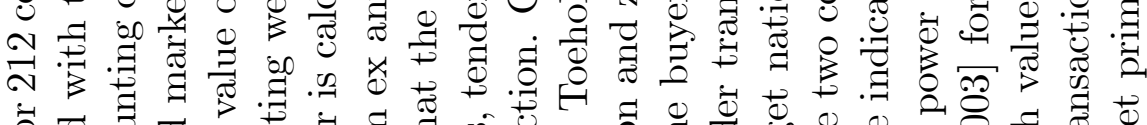

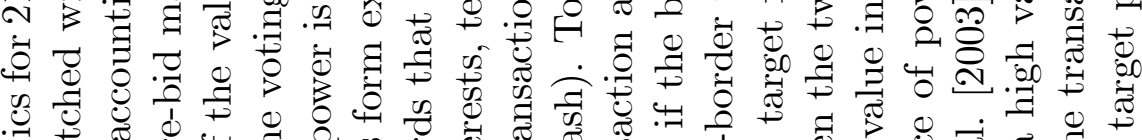

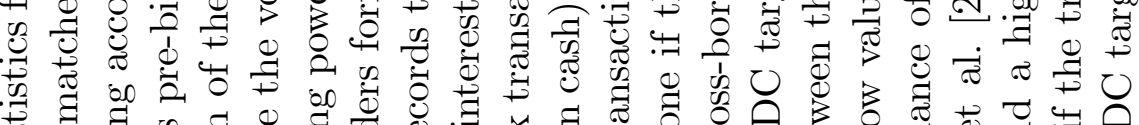

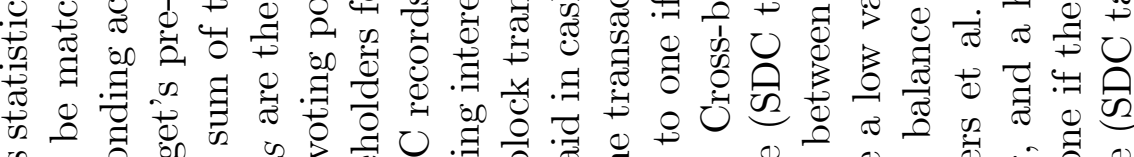

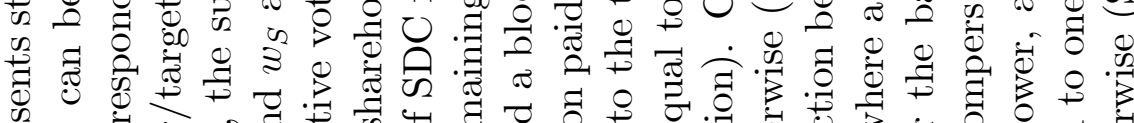

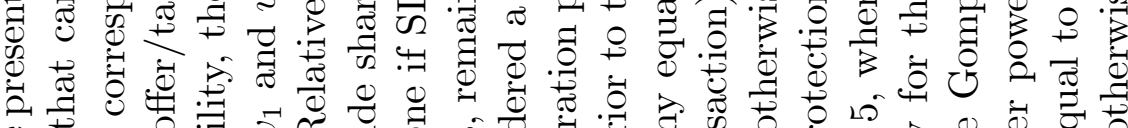

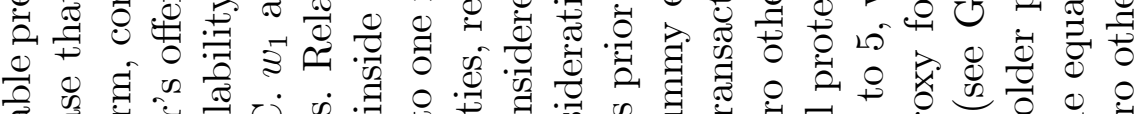

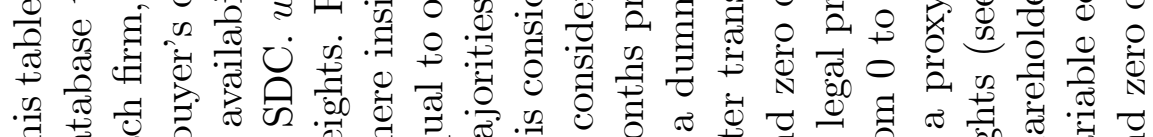

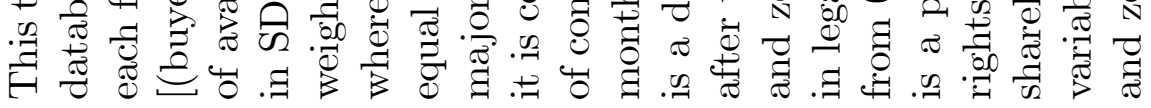




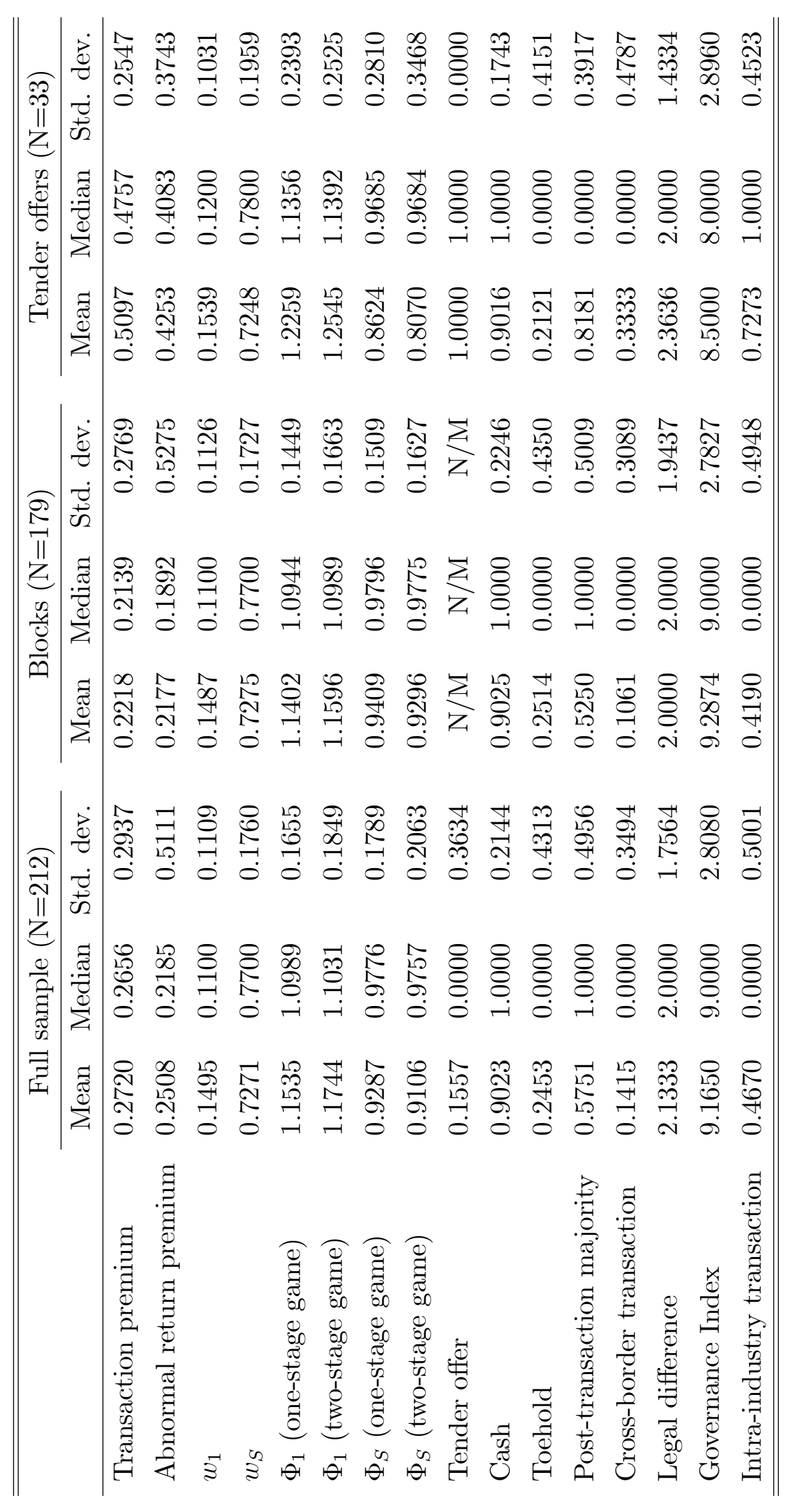




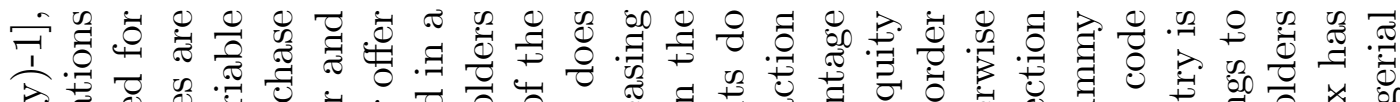

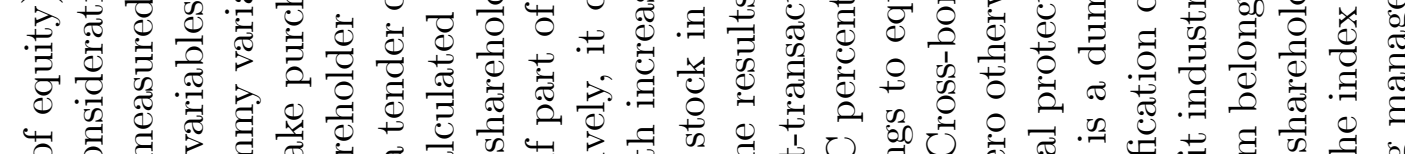

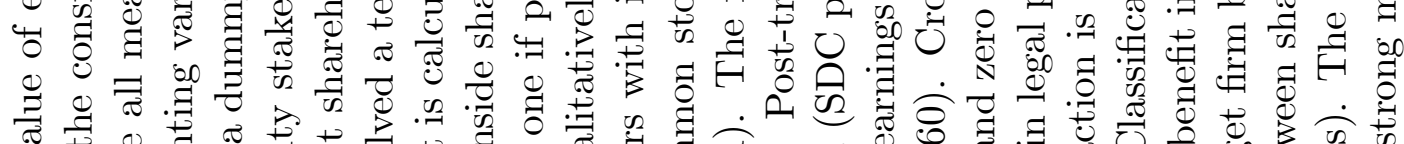

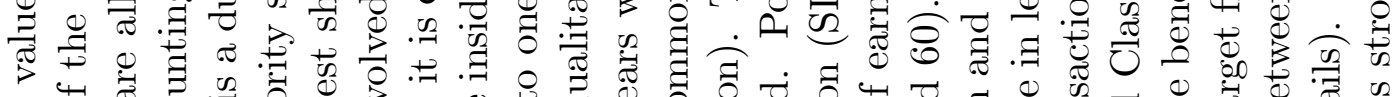

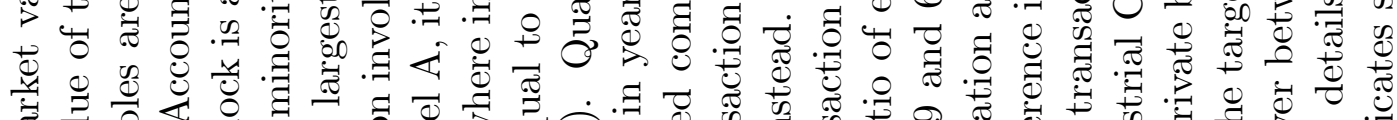

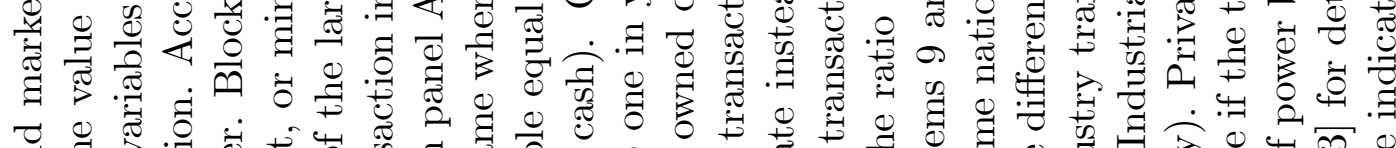

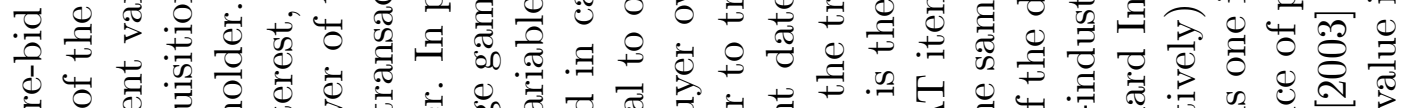

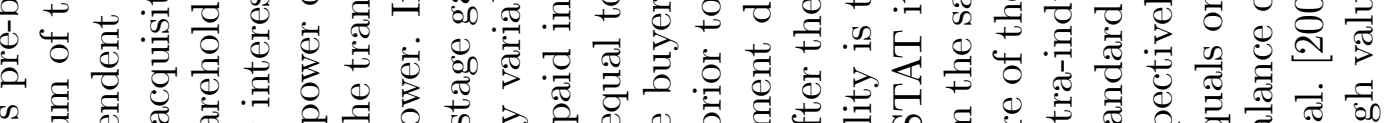
w

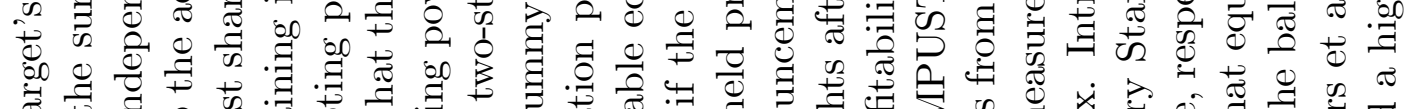

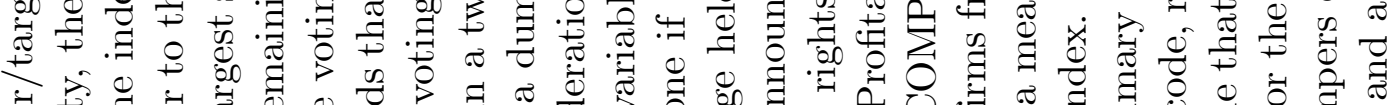

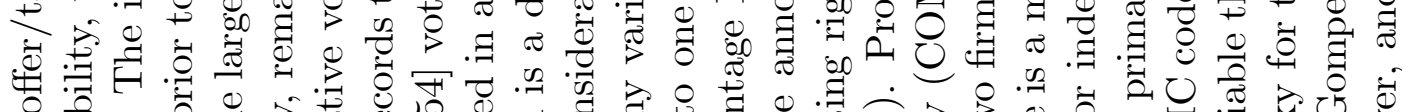

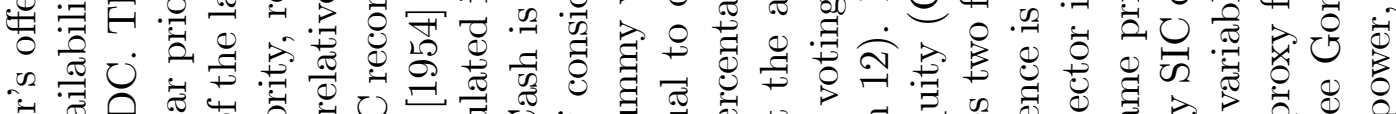

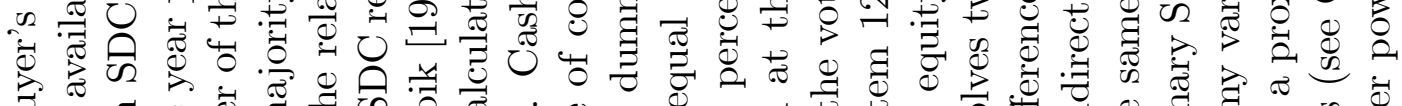

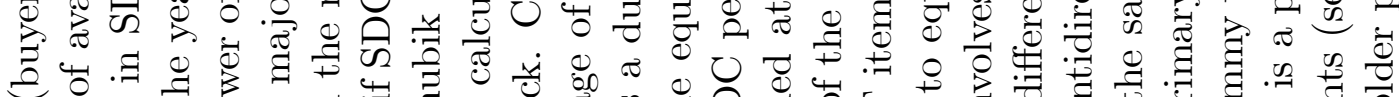

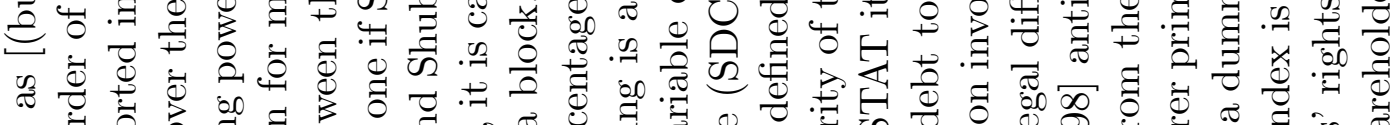

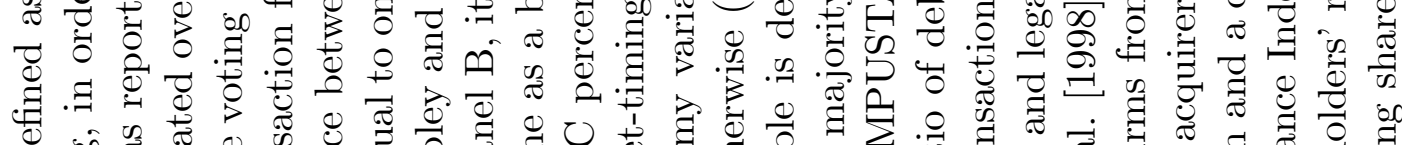

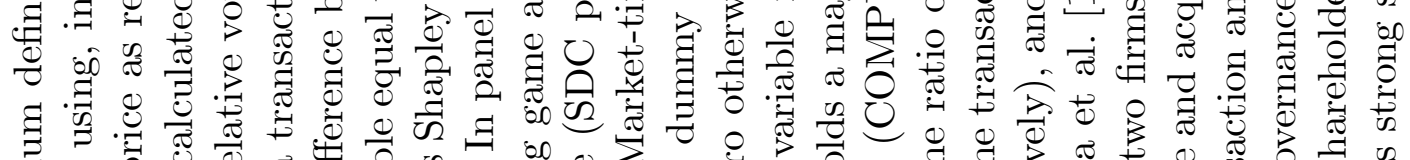

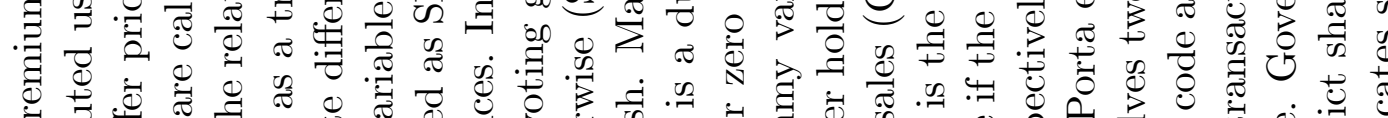

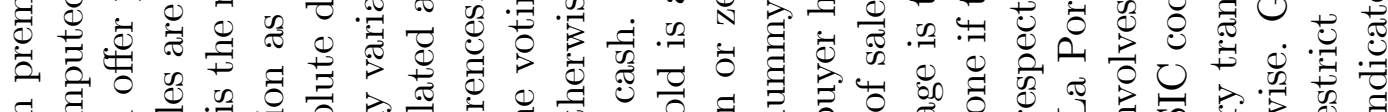

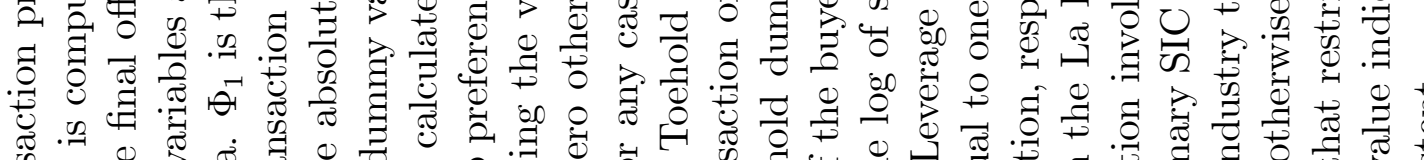

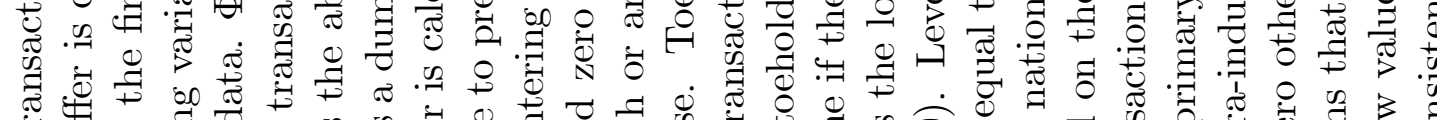

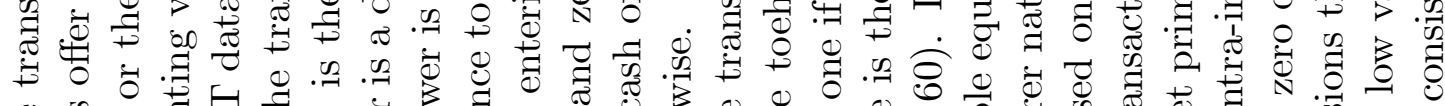

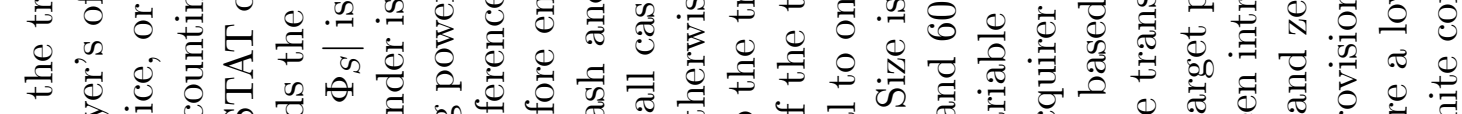

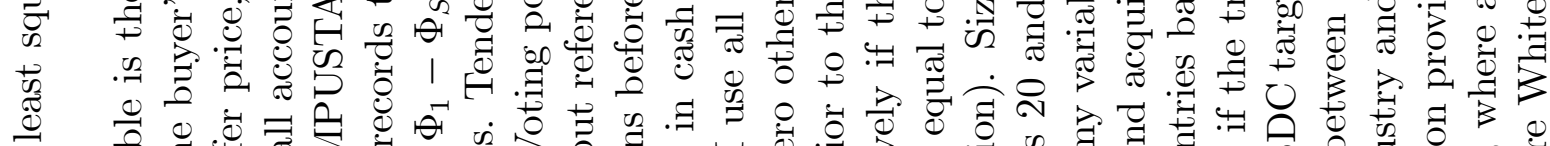

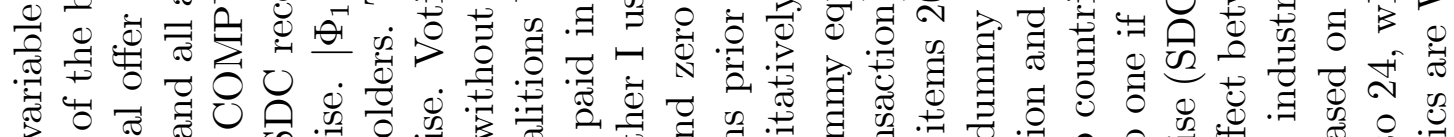

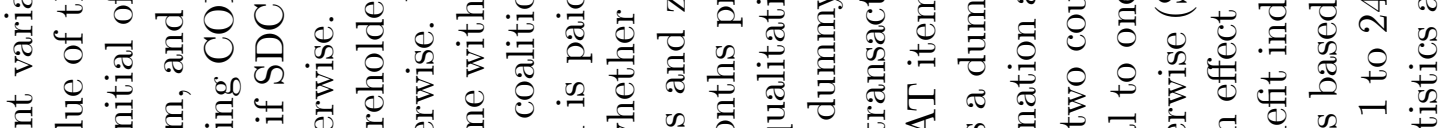

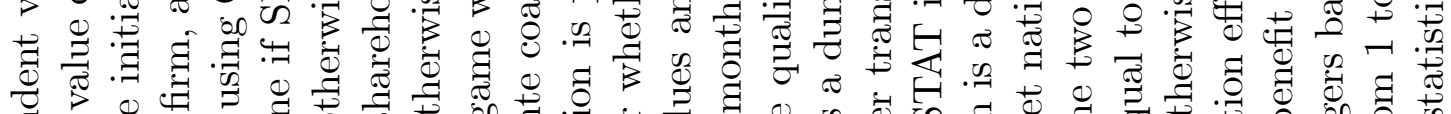

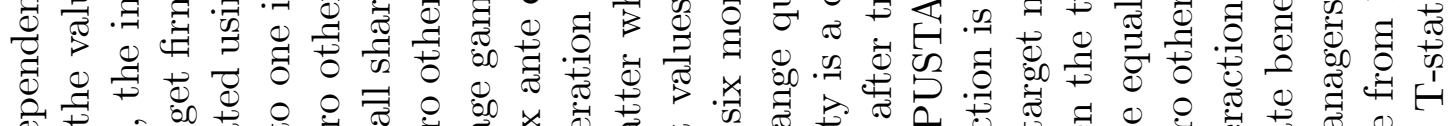

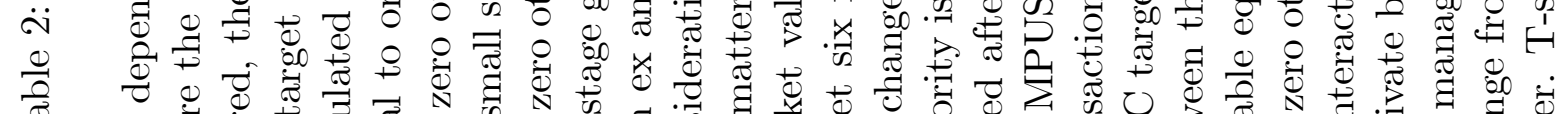

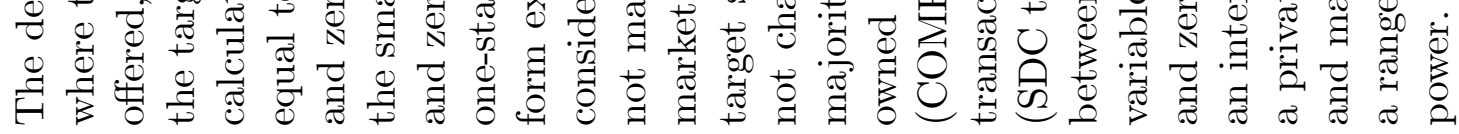




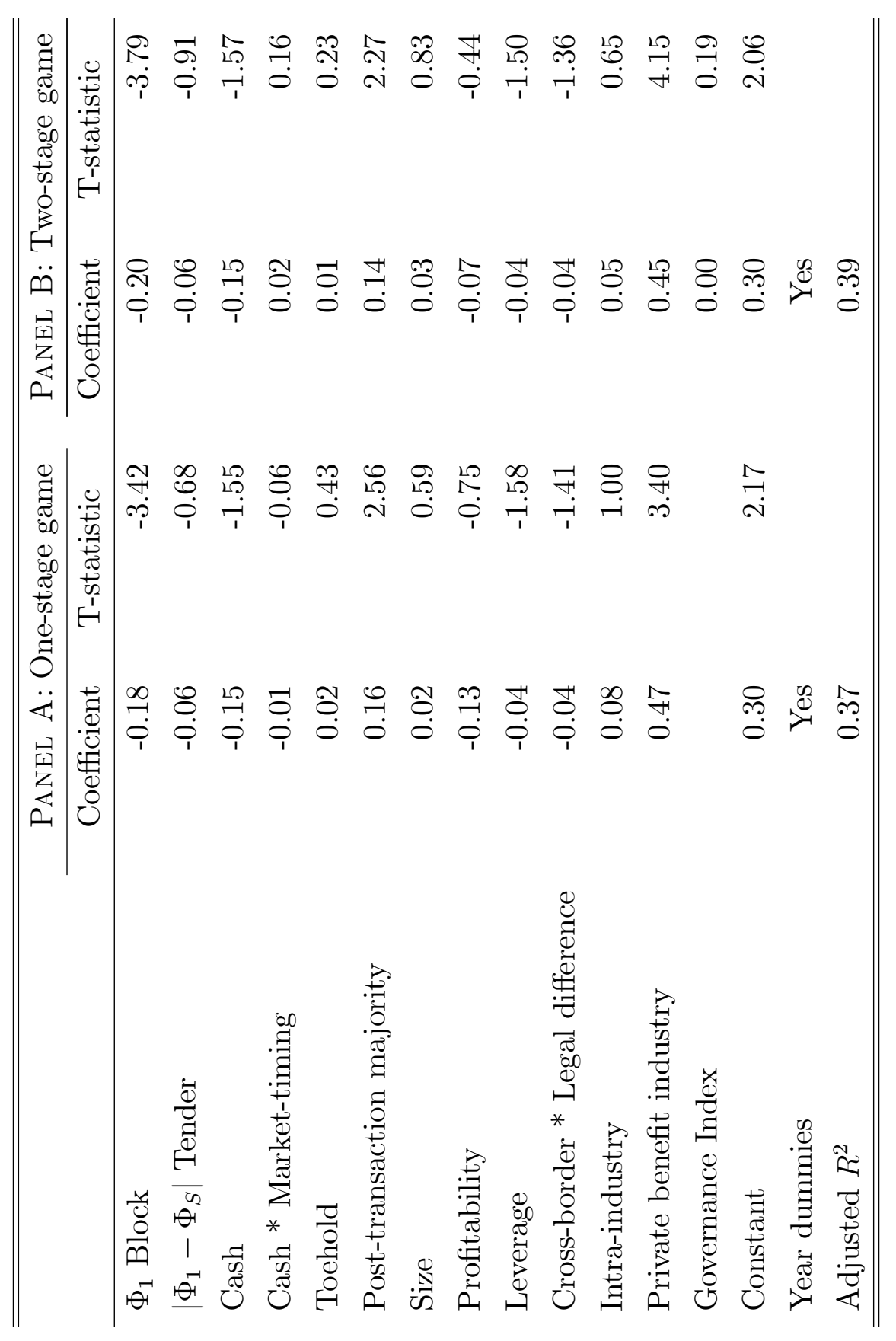




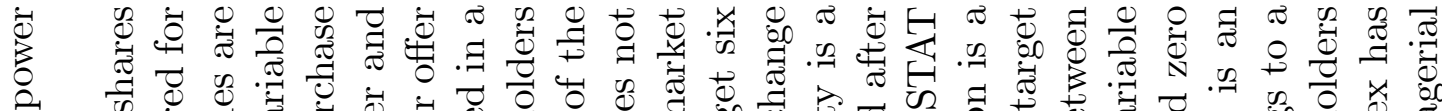

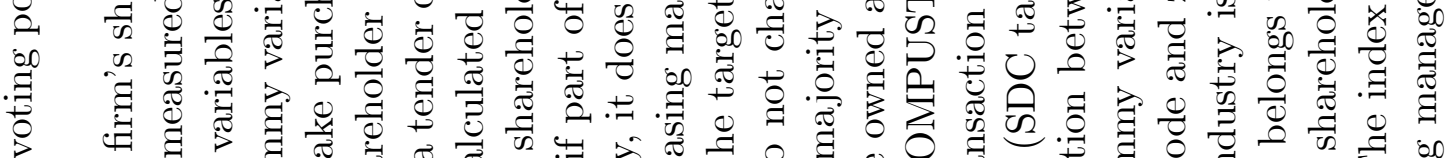

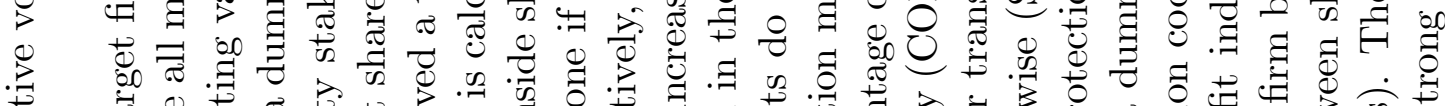

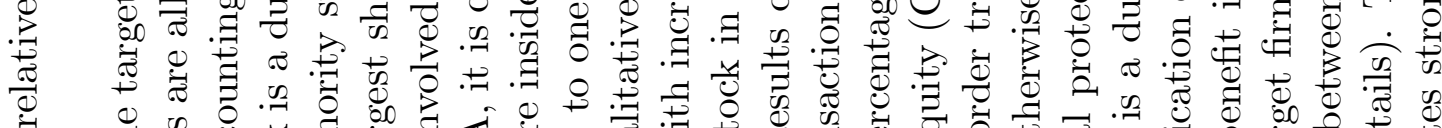

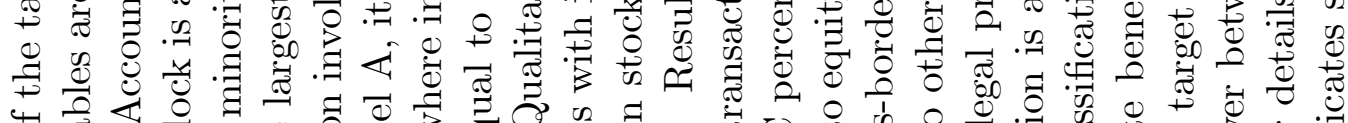

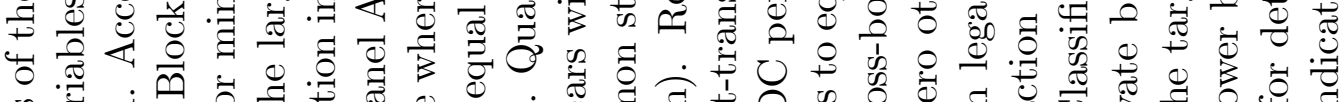

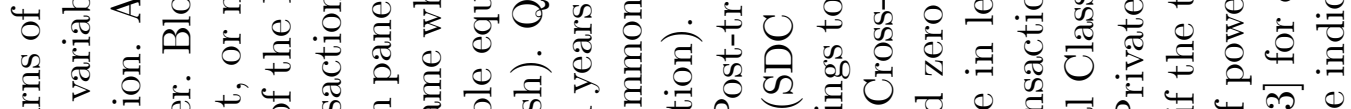

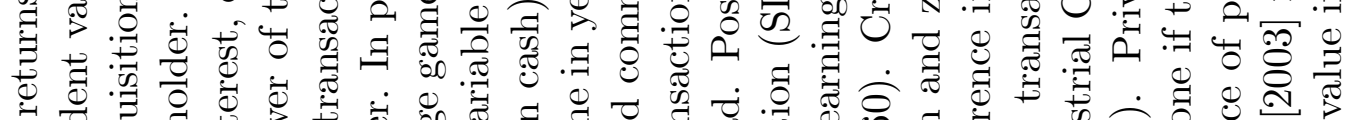

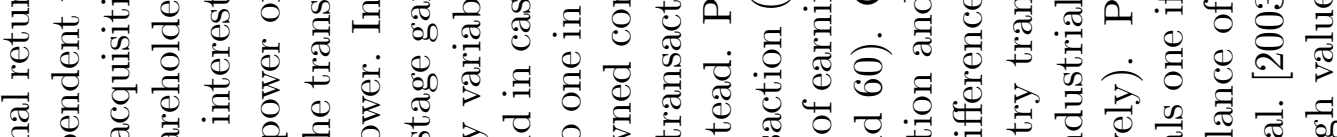

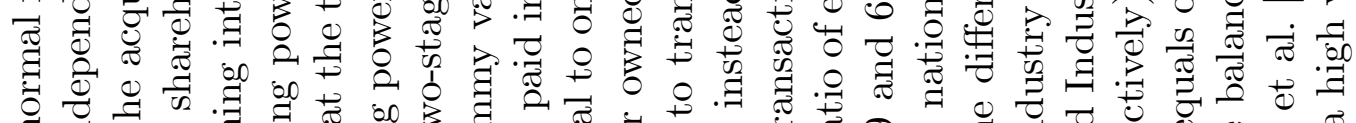

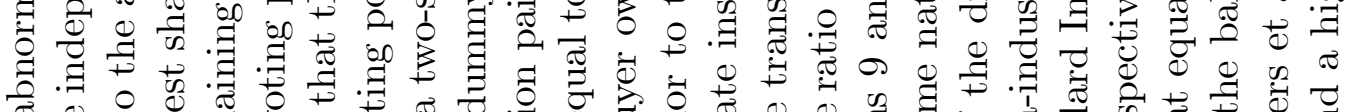

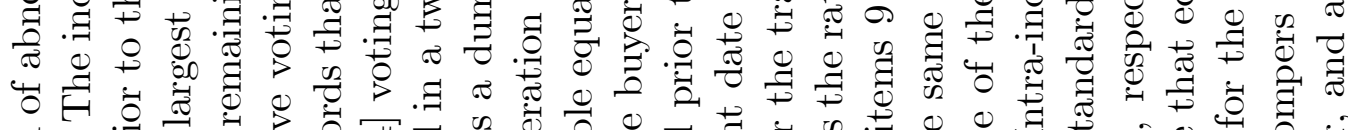

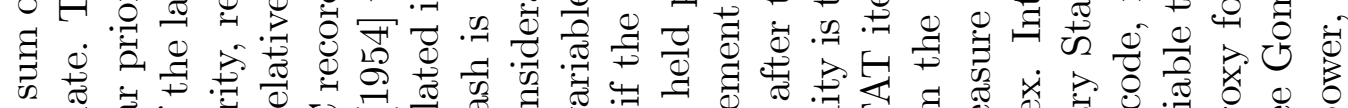

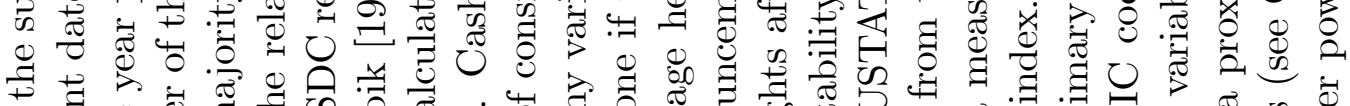

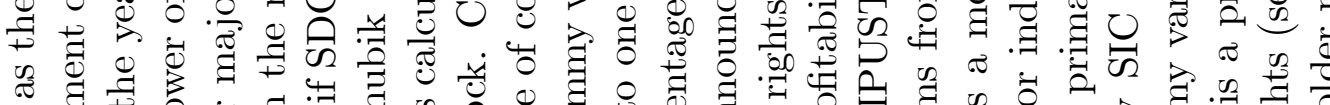

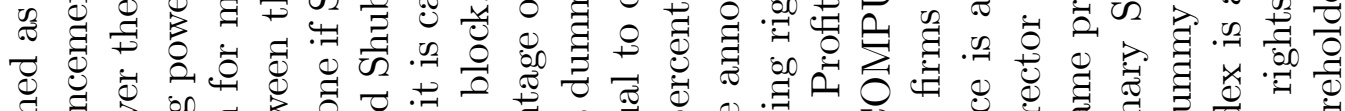

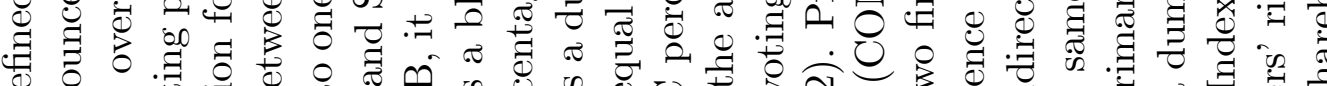
ष

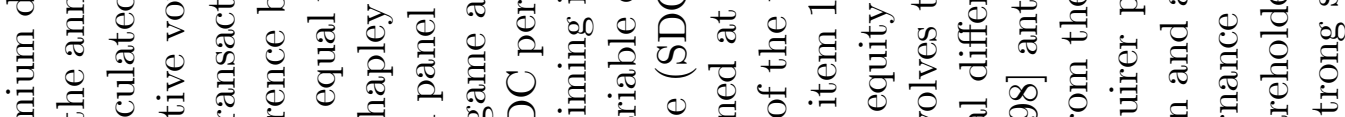

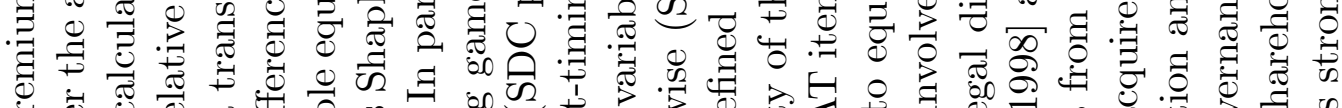

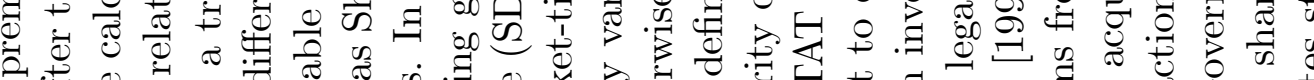

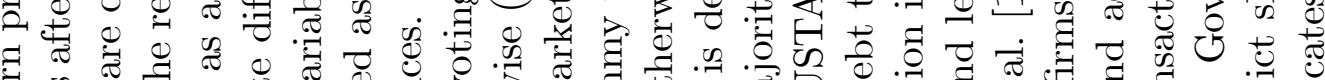

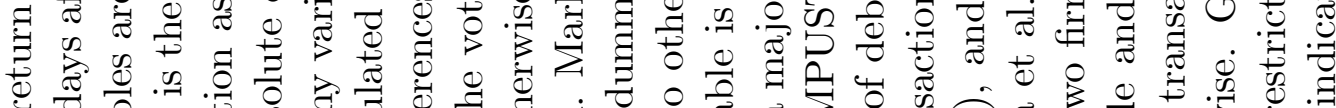

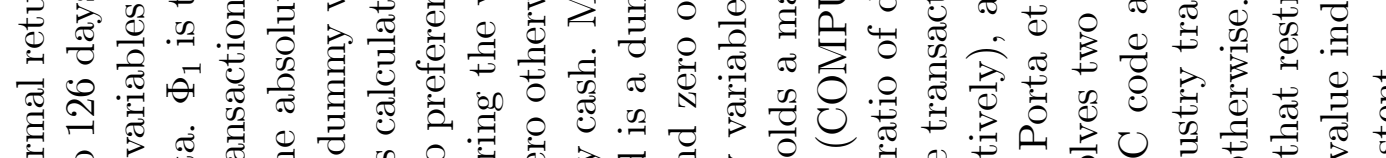

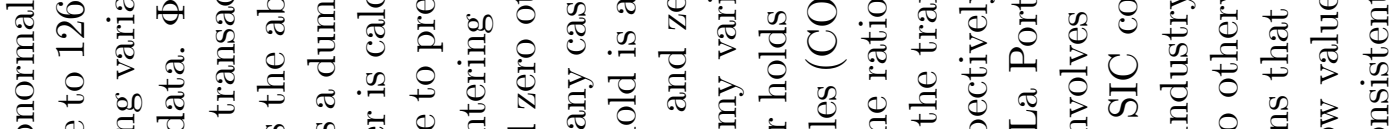

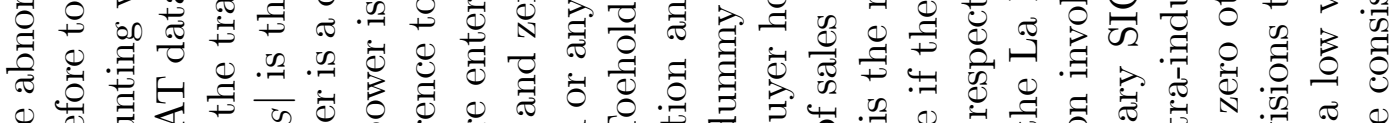

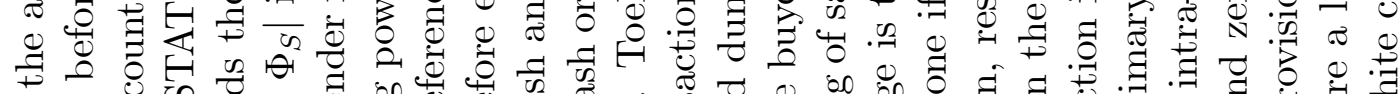

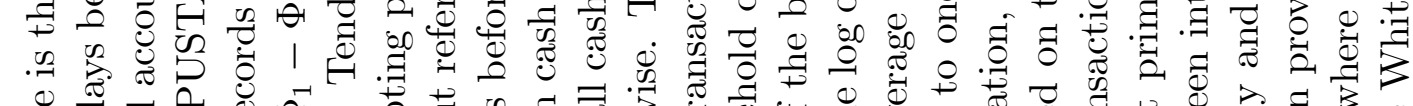

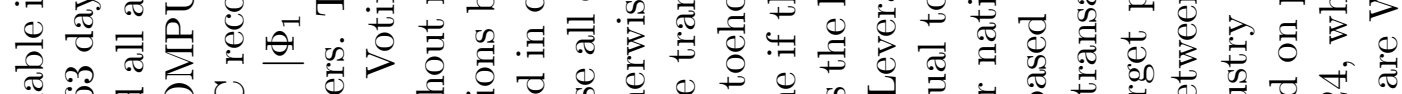

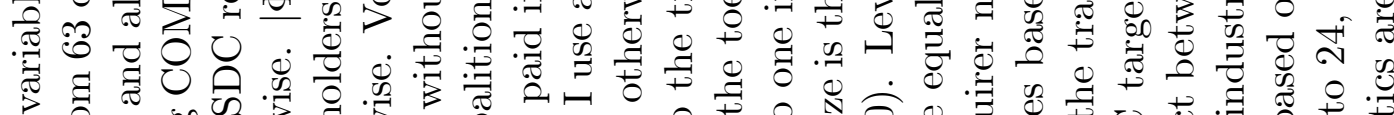

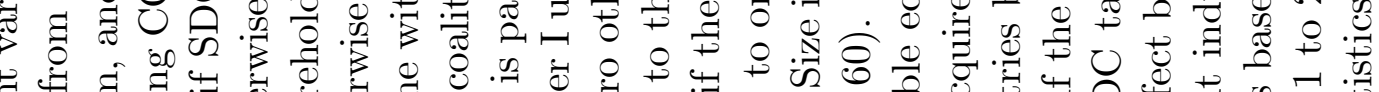

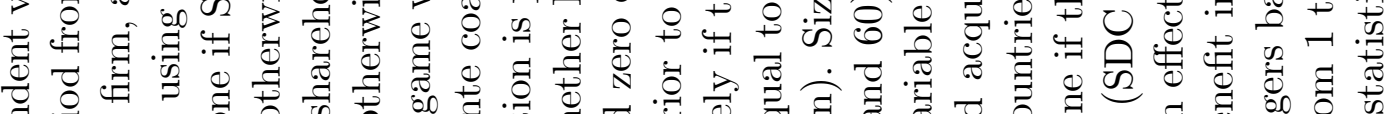

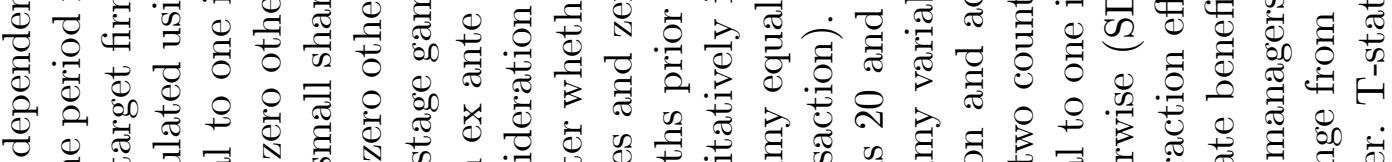

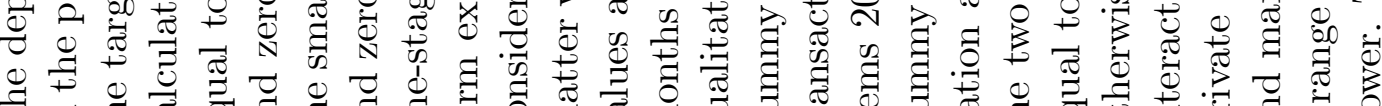

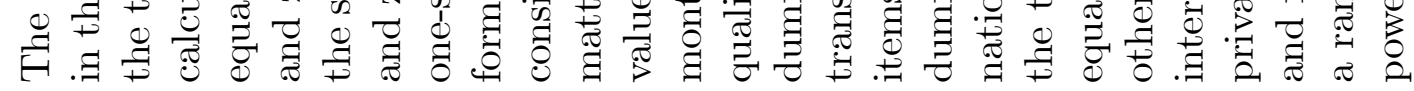




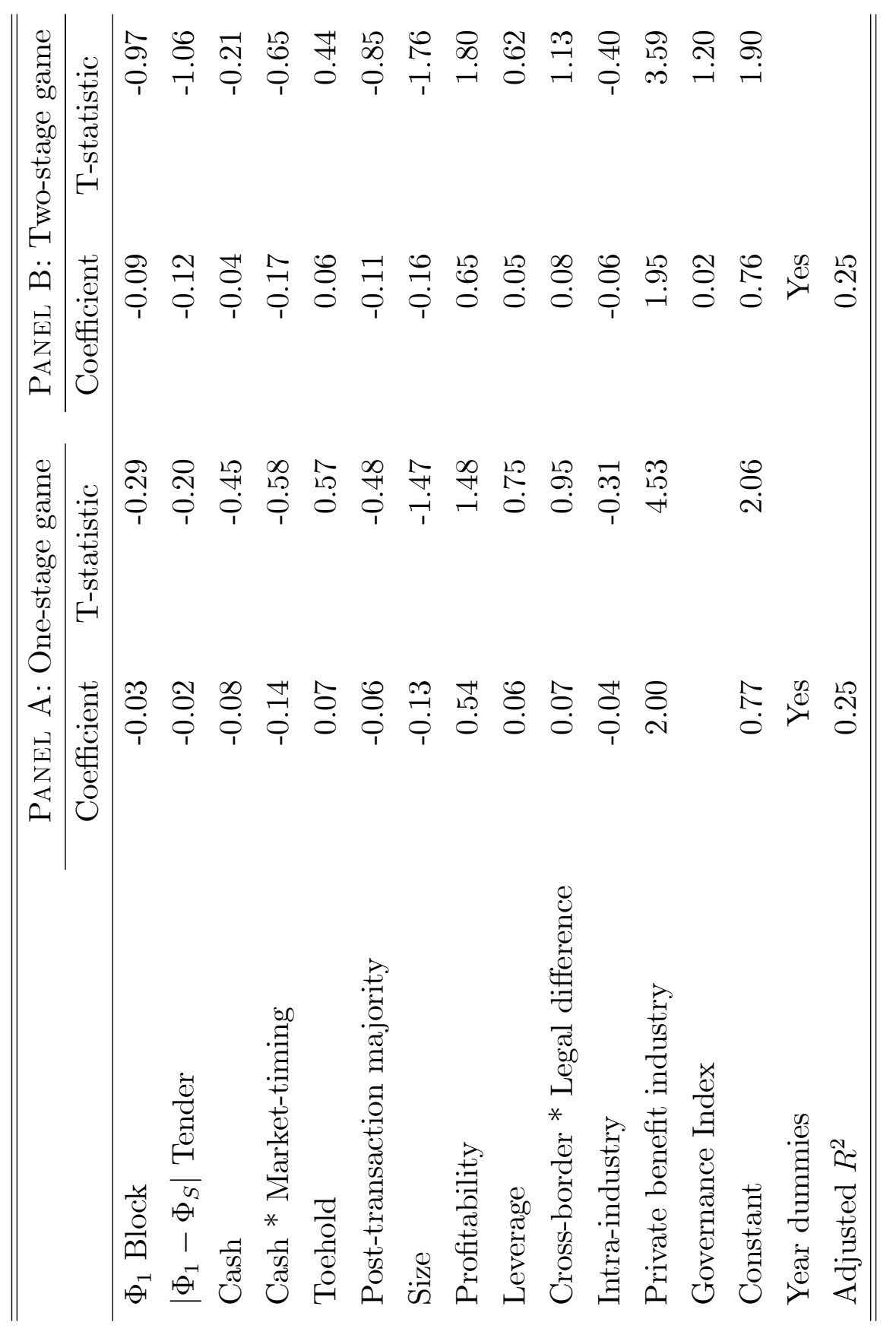




\section{Working Papers from Finance Research Group}

F-2008-03 Thomas Poulsen: Private benefits in corporate control transactions.

F-2008-02 Thomas Poulsen: Investment decisions with benefits of control.

F-2008-01 Thomas Kokholm: Pricing of Traffic Light Options and other Correlation Derivatives.

F-2007-03 Domenico De Giovanni: Lapse Rate Modeling: A Rational Expectation Approach.

F-2007-02 Andrea Consiglio \& Domenico De Giovanni: Pricing the Option to Surrender in Incomplete Markets.

F-2006-09 Peter Løchte Jørgensen: Lognormal Approximation of Complex Pathdependent Pension Scheme Payoffs.

F-2006-08 Peter Løchte Jørgensen: Traffic Light Options.

F-2006-07 David C. Porter, Carsten Tanggaard, Daniel G. Weaver \& Wei Yu: Dispersed Trading and the Prevention of Market Failure: The Case of the Copenhagen Stock Exhange.

F-2006-06 Amber Anand, Carsten Tanggaard \& Daniel G. Weaver: Paying for Market Quality.

F-2006-05 Anne-Sofie Reng Rasmussen: How well do financial and macroeconomic variables predict stock returns: Time-series and cross-sectional evidence.

F-2006-04 Anne-Sofie Reng Rasmussen: Improving the asset pricing ability of the Consumption-Capital Asset Pricing Model.

F-2006-03 Jan Bartholdy, Dennis Olson \& Paula Peare: Conducting event studies on a small stock exchange.

F-2006-02 Jan Bartholdy \& Cesário Mateus: Debt and Taxes: Evidence from bankfinanced unlisted firms.

F-2006-01 Esben P. Høg \& Per H. Frederiksen: The Fractional Ornstein-Uhlenbeck Process: Term Structure Theory and Application.

F-2005-05 Charlotte Christiansen \& Angelo Ranaldo: Realized bond-stock correlation: macroeconomic announcement effects.

F-2005-04 Søren Willemann: GSE funding advantages and mortgagor benefits: Answers from asset pricing. 
F-2005-03 Charlotte Christiansen: Level-ARCH short rate models with regime switching: Bivariate modeling of US and European short rates.

F-2005-02 Charlotte Christiansen, Juanna Schröter Joensen and Jesper Rangvid: Do more economists hold stocks?

F-2005-01 Michael Christensen: Danish mutual fund performance - selectivity, market timing and persistence.

F-2004-01 Charlotte Christiansen: Decomposing European bond and equity volatility. 
ISBN 978-87-788-2228-4

Department of Business Studies

Aarhus School of Business

University of Aarhus

Fuglesangs Allé 4

DK-8210 Aarhus V - Denmark

Tel. +4589486688

Fax +4586150188

www.asb.dk 